UC-NRLF

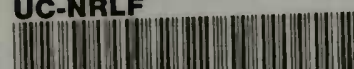

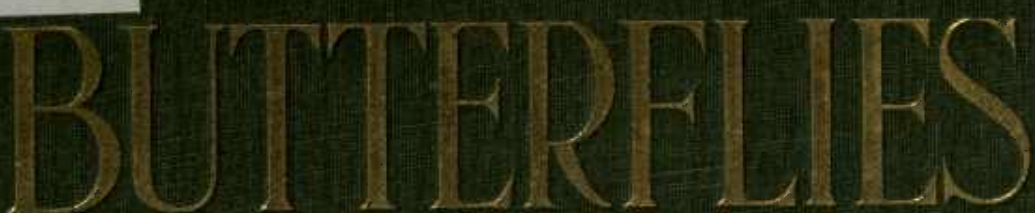

AND OTHER INSECTS

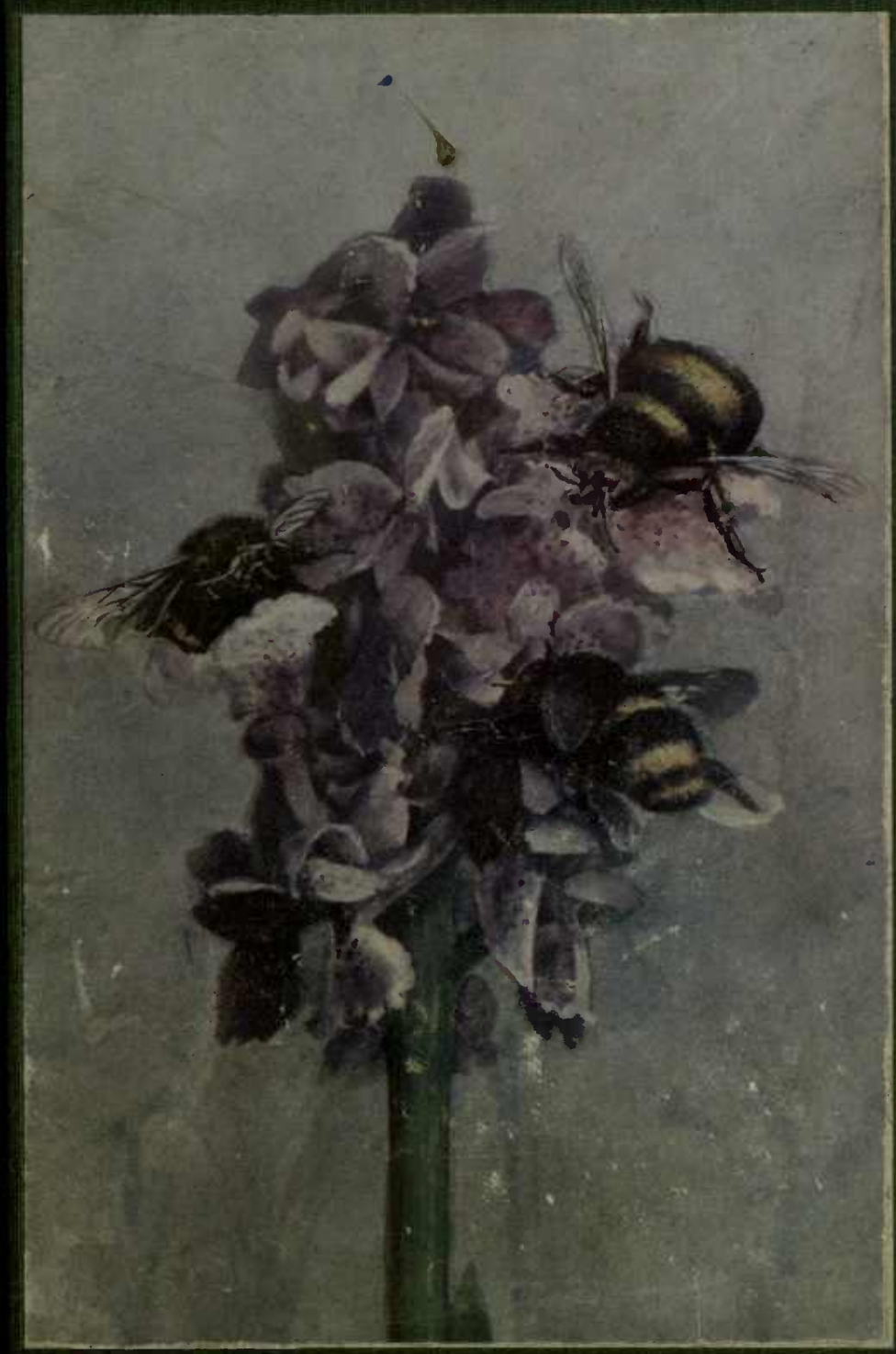



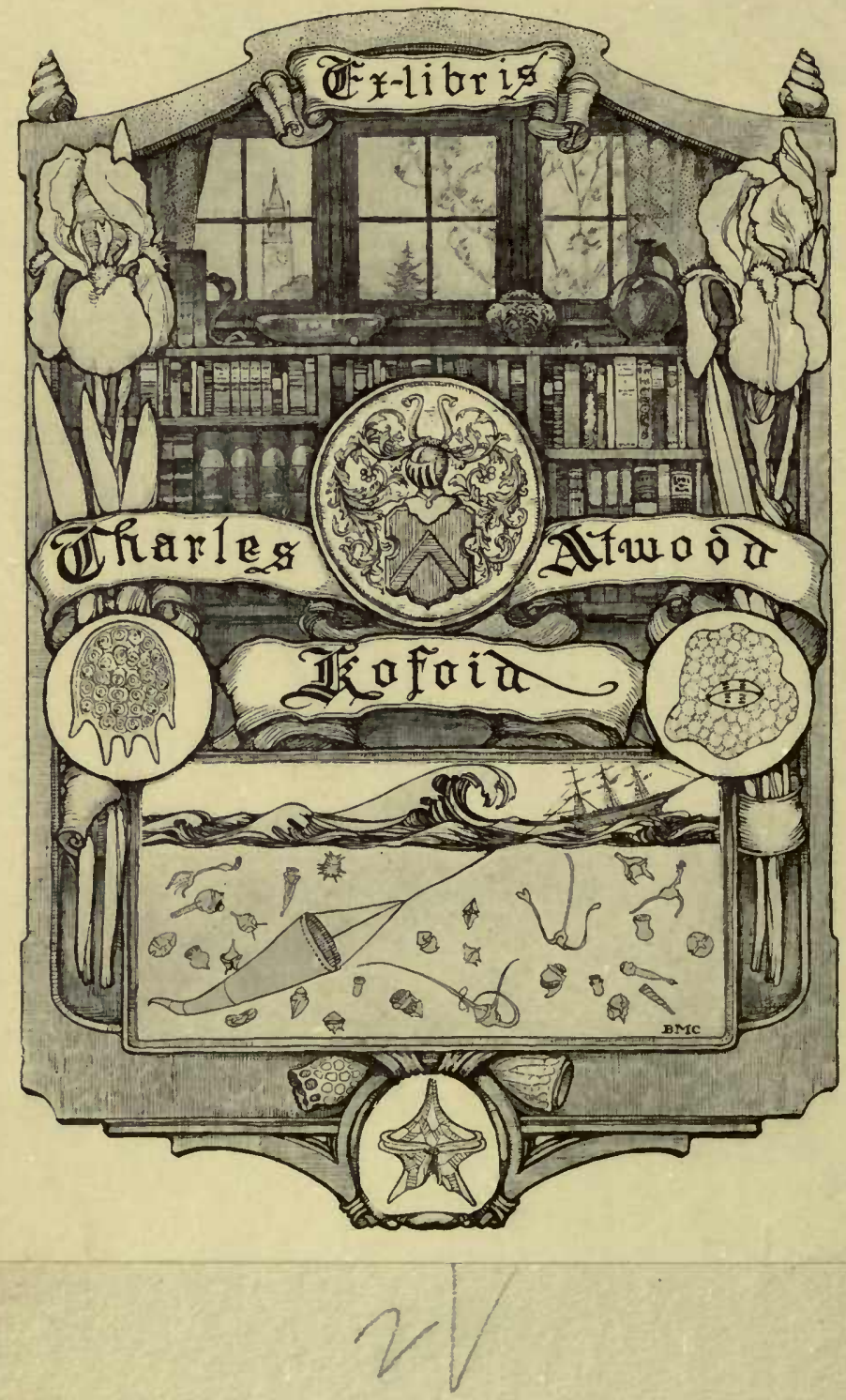


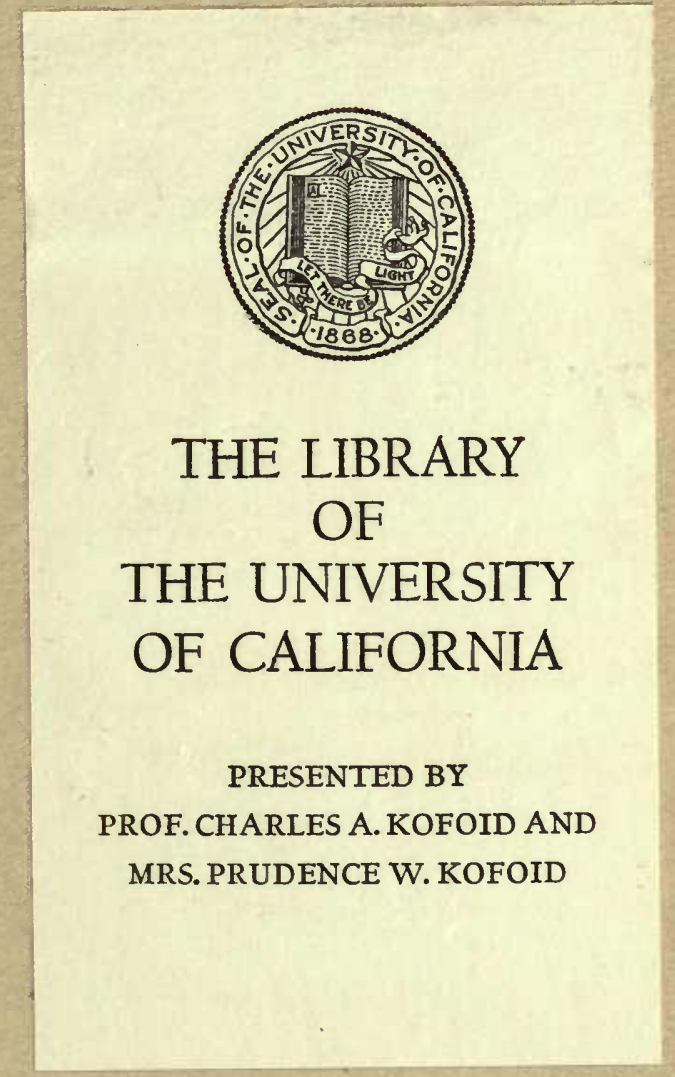





\section{British Butterflies and other Insects}






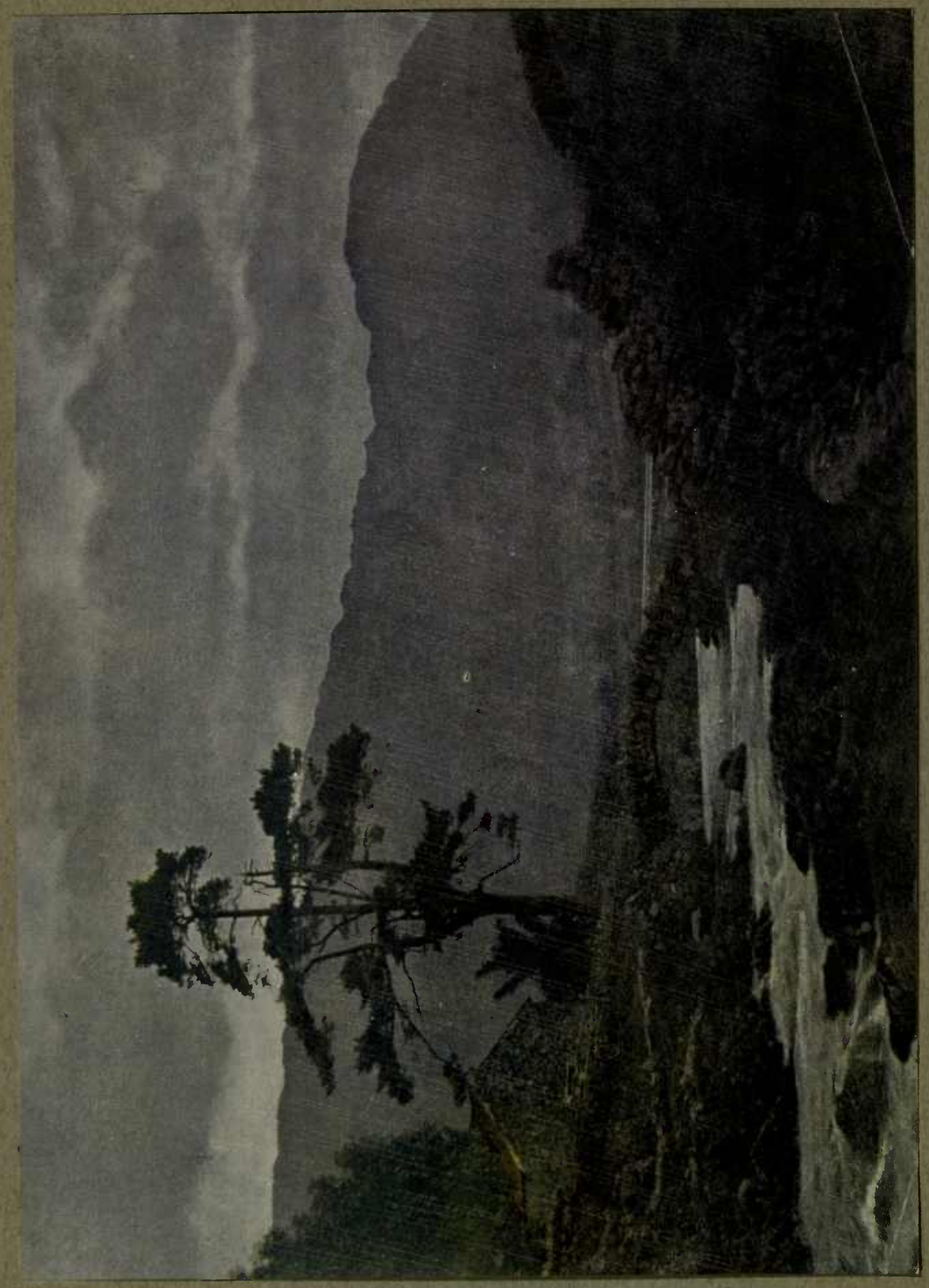

$\frac{2}{2}$

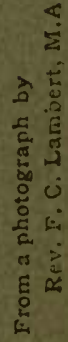




\title{
British Butterflies and other Insects
}

\author{
Edited by \\ Edward Thomas
}

Illustrated

Hodder and Stoughton

Publishers London 
Printed in 1908

Butler and Tanner The Selwood Printing Works Frome and London 


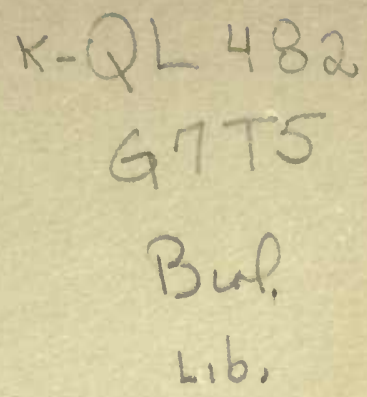

\title{
CONTENTS
}

\section{I \\ PAGE \\ SOME ENGLISH BUTTERFLIES • • • • • 3 \\ By Anthony Colletrt.}

\begin{abstract}
II
THE BEE MIND • • • • • • . . 2 I

By G. A. B. Dewar.
\end{abstract}
III
GHOST MOTH EVENINGS
By G. A. B. Dewar.

IV

THE RAILWAY EMBANKMENT

By G. A. B. Dewar.

$\mathrm{V}$ 


\title{
CONTENTS
}

\section{V}

PAGE

\section{BUTTERFLIES IN BED}

By G. A. B. Dewar.

\begin{abstract}
VI
PEARL SKIPPERS

By G. A. B. Dewar.

49
\end{abstract}

VII

ANAX IMPERATOR

By G. A. B. Dewar.

VIII

THE SPHINX MOTH . . . . . . . 6r

By G. A. B. Dewar.

IX

FIELD NOTES ON SOME ENGLISH BUTTERFLIES . 67

By Richard South.

vi 


\title{
CONTENTS
}

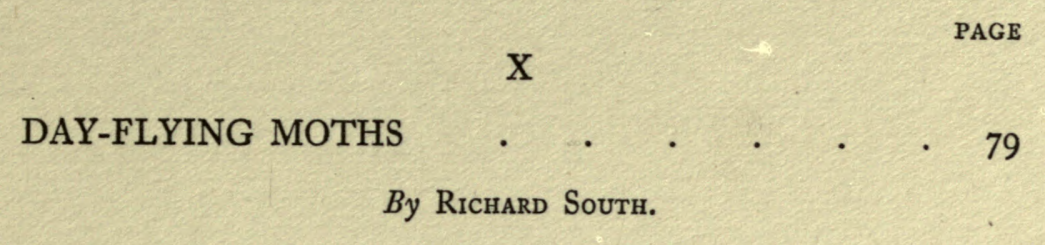

XI

THE ENTOMOLOGIST'S METHODS • • • • $9 \mathbf{I}$

By Richard South.

\begin{abstract}
XII
HUMOURS OF INSECT LIFE IN OCTOBER . . IOI

By Alfred W. Regs.
\end{abstract}

XIII

THE MAKERS OF GOSSAMER ․ . . . $\quad$ II7

By F. P. Sмттн. 

SOME ENGLISH BUTTERFLIES 



\section{I. \\ SOME ENGLISH BUTTERFLIES \\ "Unpiloted in the sun ... \\ With idle effort plundering one by one \\ The nectaries of deepest-throated blooms."}

-RoBerT BRIDges.

MotHs and butterflies alike are embraced in one great order of insects, and the scientific distinction between them is often uncertain and obscure. But the butterflies have, above all, a delight of pure and ardent living in the sunshine which is the real distinction of their race, though the needs of science may have enforced recourse to an exacter standard of discrimination based upon the form and fashion of their feelertips. There are a few moths, it is true, which love the sunshine better than the night; but no single butterfly has willing traffic with the hours of darkness, unless, exceptionally and rarely, for some syruploving and bibulous Red Admiral, which may be found still clinging drowsily in its cups to a rotting pear or plum in the warm September garden, under the canopy of a moonless sky. Even more than the 


\section{BRITISH BUTTERFLIES}

beauty of their colouring, which is by no means always greater than that of the moths, or than the absence from among their number of that dim and multitudinous fringe of mote-like life which confuses the mothworld with the shadow of specific infinity, it is this brilliant vitality, this natural citizenship of the sun, which marks out butterflies among insects with a supreme attraction and charm.

When the first day comes in March when the air is quick with awakening life, and the earth drinks deep of new, hot, golden splendour from a sun now high in heaven, the seal is set on returning spring by the great yellow wings of the Brimstone butterfly, purposefully beating down the rides and lanes like a visible concentration of the light. With him, or even before him, in the illusory brightness of some halcyon winter noon, there appear three or four other species of a different family, of which the characteristic predominant colour is deep and brilliant red. The commonest of these early spring butterflies are the Small Tortoiseshell, the Peacock with his rich eye-pattern, and the Brimstones, male and female, in their brilliant yellow and delicate primrose-green. Scarcer but still regular pioneers of spring are the Large Tortoiseshell, which has a tawnier dash in its red, and the strangely fretted Comma, with its outline like a jagged shell. These, with three or four 


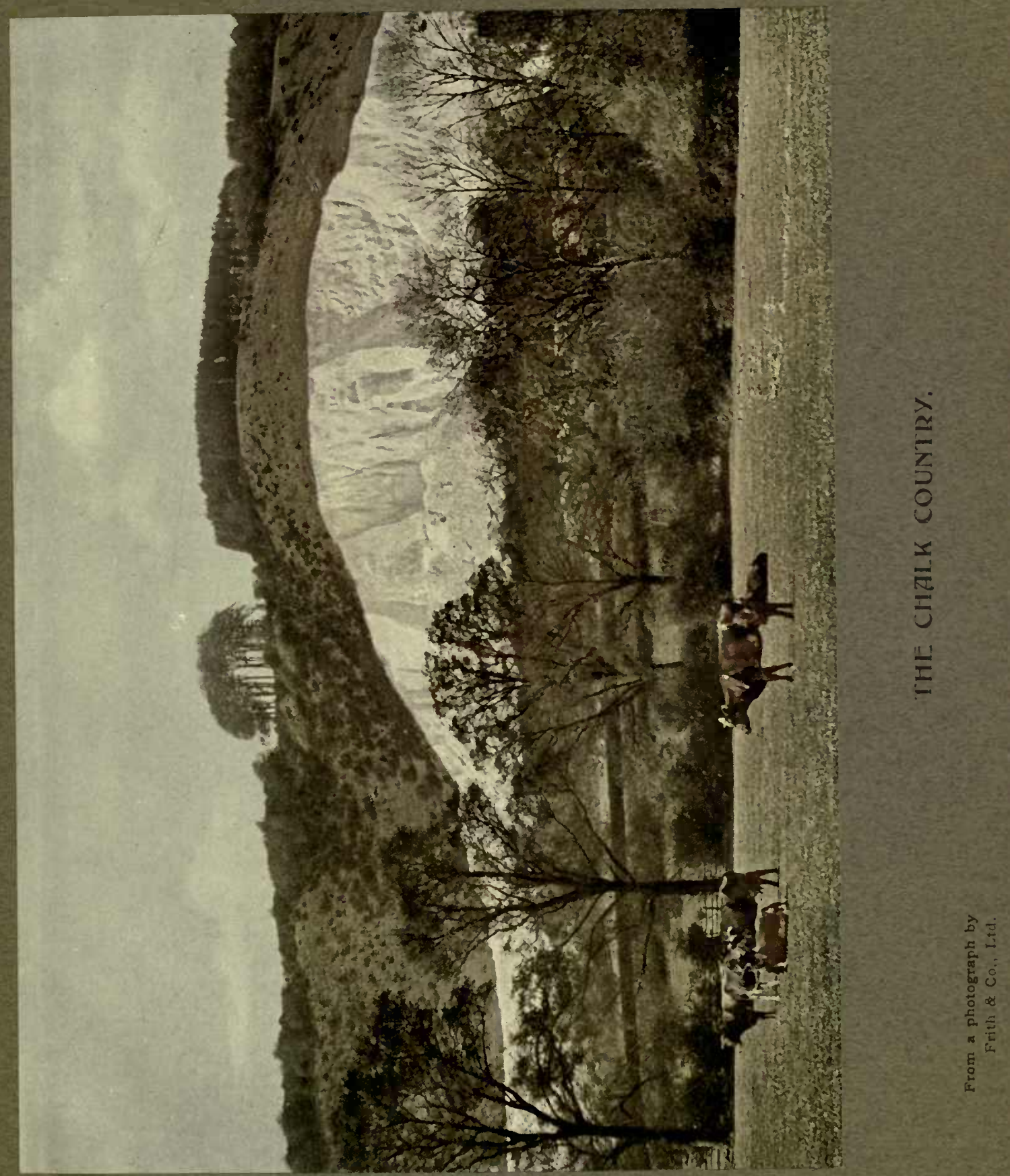




\section{SOME ENGLISH BUTTERFLIES}

others seen more rarely, make up the large and brilliant vanguard of the returning butterfly year; and yet none of this band are true children of the reviving spring, but all are age-worn survivors of last September's sun, which, by a special dispensation of Nature, have slept out the winter's dark and cold. If they are closely scanned, basking on the warm gravel walk as is the habit of the red "Vanessae," the eye will mark at once how sadly they are scarred and worn with accident and age. The strong, compact wings of the Brimstones seem usually in better case, but even the Brimstones appear tarnished and faded under the first suns of spring. The battered brightness of these hibernating butterflies in the new spring sunshine is in striking harmony with the withered and sluggish torpor which the earth still shows under the first full flood of revivifying light. The earth, too, is defaced and sore with winter, cumbered with bleached and matted herbage where the new shoots are only now swiftly springing, and bared to the brilliant sun with still arid and frost-scarred clods. Such days have all the poignancy of a siege relieved; and the touch of pathos in this contrast is nowhere expressed more fully than when a torn red Tortoiseshell butterfly, that winter has scarcely spared, alights in the new March sunshine on a golden, fresh-blown dandelion flower, brilliant in every petal with the tender luxuriance of spring. 


\section{BRITISH BUTTERFLIES}

Spring waxes and deepens, the young leaves spread and glisten where all was bare, and presently there comes the day when the first new butterflies of the year wing their way abroad in the morning sunshine, with an unstained freshness of life and colour as beautiful as the larch's misty green, or the song of the chaffinches in the limes. The day of last year's veterans is done, as soon as their eggs have been laid on the young nettle or buckthorn shoots, to bring forth in due time, through threefold mutations of development, the full brood of late summer and early autumn. In harmony with the whole tone of the spring, the colours of the April butterflies are as delicate and fresh as those of the Vanessae and the Brimstones are deep and full. The Common White of the cabbage-gardens has a cool purity of colour, as it flutters down a moist upspringing hedge-bank of blue speedwells and starry stitchwort, which we forget to notice when high summer has multiplied its numbers. Much more beautiful still is the Orange-tip of the May lanes and meadows, dusted and chequered with gold and green on its under surface, and with half the white fore-wings of the male dipped in a brilliant orange-red. It lives out its life during the flower-time of the white cow-parsley, mimicking this blossom, which it loves to haunt, by the fretted whiteness of its wings; and its pure tints brightly flushed with mounting summer 


\section{SOME ENGLISH BUTTERFLIES}

seem the very incarnation, in light winged form, of the essential spirit of May. Another of the first spring butterflies which wear all the tender freshness of the season is the Holly or Azure Blue, earliest of its tribe, and almost more beautiful than them all in its cerulean lustre, backed with a frosted silver more delicate than the seed-pearl pattern of the Common Blues of the June hayfields. White butterflies by the warm bank where the adders bask, sun-kindled Orange-tips on the white hemlock and pale mauve cuckoo-flower, and Holly Blues flickering headlong out of the sky that hides them across the dark sheen of their lustrous home boughs - all the voiceless beauty of the mounting spring is in those wings, and we lose, when they vanish, the last of the childhood of the year.

The tints of the butterflies deepen as the year advances, and from month to month, by meadow, woodland and moor, the quivering pictures multiply that they inlay with their wings among the blossoms and verdure that each species loves. For each butterfly has its own flowers, its scenery, its weather; the Wood Argus, if carried by rough winds into the open meadows, is as sad and hurried a fugitive as Noah's dove upon the unrestful waters, and there is no home among the glades and shadows for the Marbled Whites of the downside, or the Graylings of the heath and wold. This dependence upon particular localities, and on the 


\section{BRITISH BUTTERFLIES}

food-plants of the caterpillars which they support, has naturally had a great effect upon the increase and diminution of particular species. With the gradual drainage of the fen countries, the Large Copper has become wholly extinct, and the Swallowtail is now very rare and local ; on the other hand, the Large and Common Whites undoubtedly owe their commonness at the present day to the universal cultivation of the cabbages and other garden plants on which the caterpillars feed. Before such green garden-stuff was universally grown in England, these Whites must have been among the scarcer English butterflies. Even to-day, on such a remote fringe of British civilization as some of the outer Hebrides, it is strange to see how the Common White is a scarce insect haunting the few island gardens, while the desolate peat-moors are covered with the rare Large Heath, a butterfly of the waste and morass which is scarcely seen in England, and only in certain narrow and desolate areas. The disappearance of the British Large Copper is all the more to be regretted since it formed a distinct island species which had acquired, in ages of separate life, marked differences from the kindred butterfly of the Continent, which is still anything but rare. The British race of the Camberwell Beauty, the magnificent cousin of the Peacocks and Red Admirals, which also seems to have become extinct within the memory of men of middle age, had 


\section{SOME ENGLISH BUTTERFLIES}

also a definite distinction of colour which separated it from the rich and stately insect still to be seen by every August visitor to the Alps or the Rhine. Even within the bounds of England itself, where there is no such rigorous separation of races as is imposed by the barrier of the sea or great mountain ranges, the tendency to such local differences is often seen at work. Those large and handsome moths, the Fox, the Oak Eggar and the Drinker (of which the two former are as sunloving as the Brimstone itself) display a remarkable difference between the big, bright-coloured insects of the South, and the small, dark race of the North.

As April swells into May, and May into June, the tribes of the butterflies increase, until about midsummer and hay-time the greatest number of species are on the wing at any one moment of the year. In these earlier days of summer the brightest pictures of butterfly life are to be seen in the broken woods and copses, and all such clean, luxuriant places where the sun shines freely down upon a mixed carpet of many-coloured flowers, and green bosses of irregular verdure mounting to the tree-tops in the light. As the woods and copses deepen to the full luxuriance of May, year by year the quiet, blossom-starred rides are filled with the chequered red-brown wings of the two smaller Pearlbordered species of Fritillary, first of their splendid tribe. No less faithful to the wood-ride and to May 


\section{BRITISH BUTTERFLIES}

are the Large Skippers, spinning from leaf to flower on wings of a kindred golden brown, but of a hue not quite so rich and warm as the true Fritillary glow. With the reddish and the golden brown of those sun-loving, companionable wings, there comes up linked in memory the whole bright yearly mosaic of the copses of flowery May. Everywhere, in the herbage of the rides, still richer with promise than with fruition, there shines the veined turquoise blue of the self-heal or prunella, and the lighter yellow spikes of dragon-mouthed cowwheat; spotted orchises shine in the moister grassy places, and tall, stripling thistles begin to push skyward their tight purple knobs. On the blue and the purple blossoms quiver the rich brown wings of the Skippers and Fritillaries, and among them are always to be seen, in the true May copses of southern England, two slender-bodied Geometer moths,- the cool, shining Silver-ground Carpet, which seems so common as to overflow into the daylight from its secret hiding-places, and that welcome and delicate harlequin, the Speckled Yellow, in his fancy dress of warm chocolate and orange. The Grizzly and Dingy Skippers are also abroad in May; but they are hardly such thorough copse-butterflies as their largest brothers, friends of the early Fritillaries, and their darker colouring does not combine so vividly and characteristically with the bright spring flowers. 


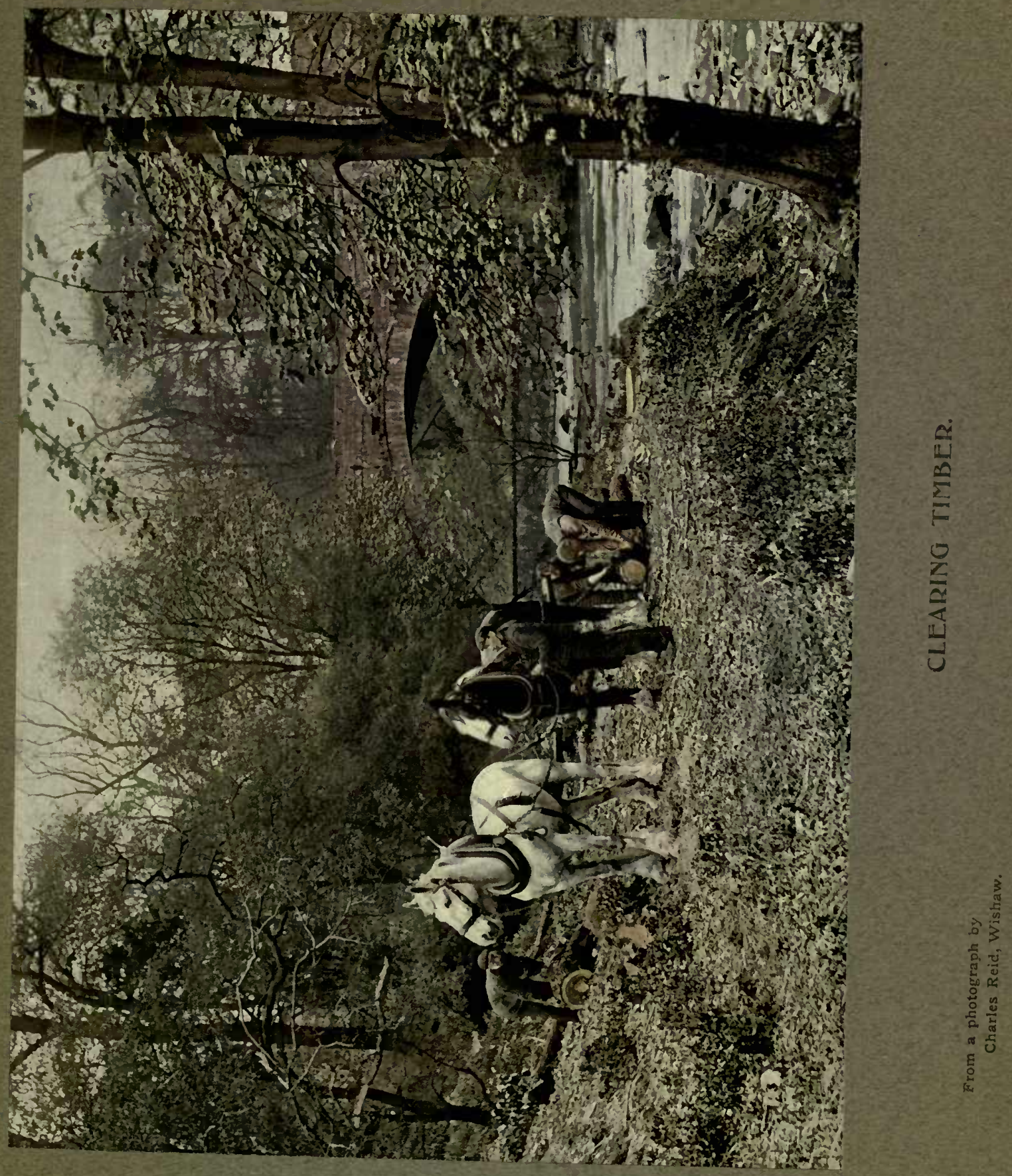




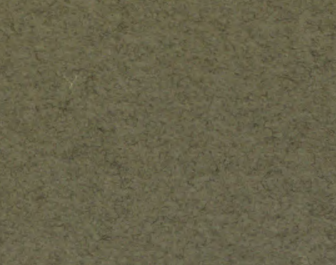

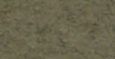

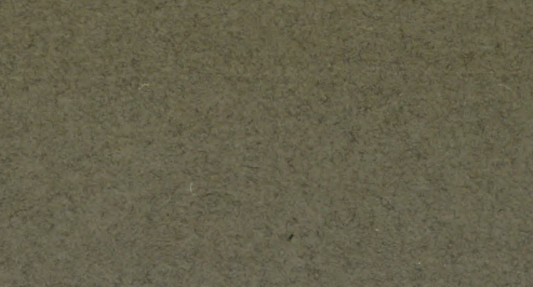

- ing

S.

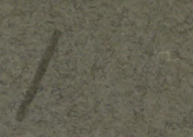

Ning

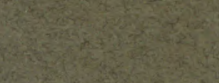

5.

tines

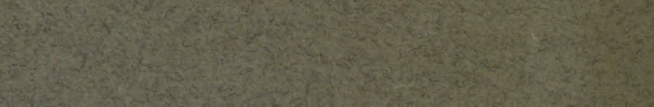

(4)

Sint

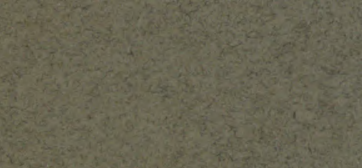

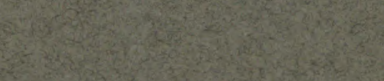

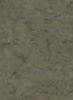

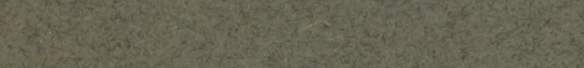

Tisis

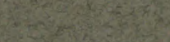

$\sin ^{2} \sin ^{2}$

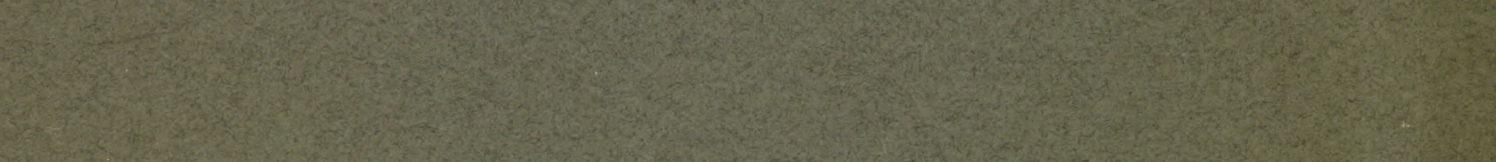

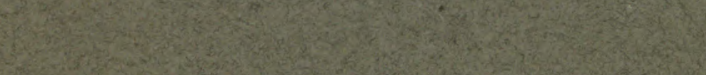
W

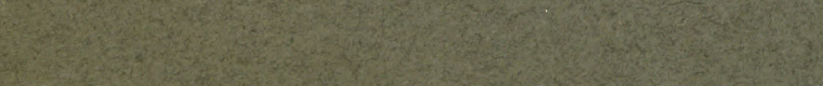

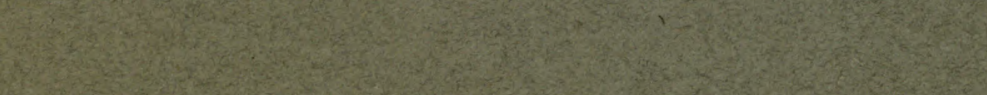

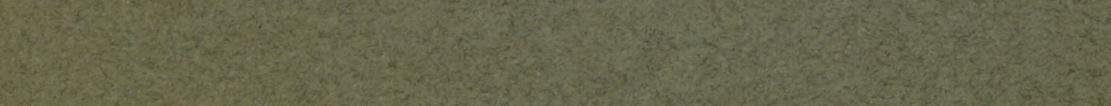




\section{SOME ENGLISH BUTTERFLIES}

The butterfly-pictures of the year grow no less distinct and characteristic as the verdure deepens under midsummer skies, though they multiply greatly in number, and spread from their earlier sheltering coverts across the whole face of the land. In the June copses, when the carpet of cow-wheat and prunella has been submerged by the rising growth, the frosted silver of the bramble blossom shakes itself to birth over the uncurling fronds of bracken; and when the cool, white bramble-blossom is born in the middle of year, then the lordlier Fritillary monarchs come forth to bask and feast upon it in the glades. There is no more beautiful picture in the midsummer woods than the deep, golden rides of oak and hazel and springing bracken, where the High Brown and Silver-washed Fritillaries seem the proud and conscious monarchs, sailing down the fair-way of the sunshine on broad wings of deepened sunlight glow, or fanning and poising in ecstasy on some large June flower, while the sheen of the silver mail of their under sides flashes for a moment and is withdrawn again from the light. Now, too, in woodland and leafy places the midsummer sunshine brings forth the smaller but beautiful Hairstreak butterflies, of which even the commoner species are curiously fitful and capricious in their periodic appearances. The Green Hairstreak is perhaps the most generally distributed of all this tribe; but it is the Purple Hairstreak 


\section{BRITISH BUTTERFLIES}

that appears, in certain summers, in such large and brilliant companies as to become one of the most conspicuous of the butterflies of the wood. Often the high oak-crowns, or the lower sapling shoots, are alive in June with the shot purple of these busy little butterflies, dancing and resting on the sprays and extremities of the boughs; and sometimes the fancy takes them to descend in mass to the bramble-blossoms of some woodside hedge, where the orange-dotted grey of their under wings contrasts in singular beauty with the rich velvety bloom and flashing plaques of their upper surface. The bloom of the Purple Hairstreak is peculiarly delicate and fugitive, even for the gloss of a butterfly's wing; the lightest touch destroys it, and its frailty is only equalled by the dark velvety green of the larger, glade-loving Ringlet, with its varying series of fine golden circles, which flaps abroad, in unconquerable, somnolent hardihood, even under the wettest and most lowering skies.

In the week when the days are longest, the hayfields and hedgesides suddenly become alive with the common Large Meadow Brown, a butterfly which is even hardier than the Ringlet of the woods, and through long weeks of forbidding and flooded summers, is sometimes almost the only butterfly to be seen. It belongs to the same great general group as the Ringlets, a group which includes not only its own warmer- 


\section{SOME ENGLISH BUTTERFLIES}

coloured kinsman, the Small Meadow Brown, but also the rare Large Heath and the very common Small one of every waste and grass-patch, the Wood Argus, the warm, stone-basking Wall or Gatekeeper, the Grayling of the July wolds and moorlands, and numerous butterflies more. Often by the very side of the Swiss glaciers, some sober, graceful little insect may be seen contentedly basking on the hungry boulders, and this will be one of the "Browns" ; and on our own Cumberland mountains, never at a height much less than 2,000 feet above the sea, there dwells one dusky, orangeflushed little creature, the Mountain Ringlet, which is our special English representative of the Alpine butterfly fauna, and a relic of the glacial age. There is a rare pleasure in seeing this valorous film of life emerging to battle with his peers and to rejoice in the keen, high mountain sunshine, when the cloud-world rolls away from the high Great Gable grass-slopes, or the shores of Sprinkling Tarn, under huge Bow Fell, and the eye ranges afar, over peak and cloven dale, to Man in the western sea.

But even before the swarm of homely, flapping Meadow Browns suddenly appear with new June suits in the meadows, the hayfields and open commons have been mustering their tribes of butterfly life. When the large ox-eye daisies begin to fill the fields with pools and lakes of silver, the Common Blues appear 


\section{BRITISH BUTTERFLIES}

in their multitudes upon the blossoms of the standing grass, and are henceforward a constant feature of the summer. They are swiftly followed by many others of their beautiful tribe; and all of them are creatures of the grass fields and the blossoms of the grass, unlike the earliest Holly Blues of April, which haunted the outer sides of sunny shrubberies and thickets. Another brood of the Holly Blues appears, indeed, in late July or August ; but with this exception, the Blues are characteristic butterflies of the fields and downs. Most noticeable among them are the large, pale-winged Chalk Hill Blues, whose filmy, clouded azure seems to reproduce the heatdimmed lustre of the skies of their native July, just as the Holly Blue had the fresh skies of April in its wings, and the Common Blue the midsummer brightness of June. Most brilliant and burnished of all is the colour of the Clifden Blue, a local but not uncommon butterfly of southern hills, where, too, the dusky Small or Bedford Blue is often to be found, dancing or drowsing, among the wild down hay-crop of June. The common Brown Argus is a little Blue that is no blue, but has the upper surface of its wings of a rich, dark brown, with a border of orange dots; the male of the Common Blue is also much smaller and duskier than the female, but it has always a bluish-purple gloss in the middle of the wing which distinguishes it from the Brown Argus, 


\section{SOME ENGLISH BUTTERFLIES}

often seen dancing beside it on the same fields and hillsides. From late May to the time of the autumn frosts the fields and healthy places are also brightened by the Small Copper, a kind of fox-terrier among butterflies, inquisitive, pugnacious, and full of vigour and brisk attractiveness. Sometimes in the heat of the dogdays, when the hay is all carried and the dewless meadows parched and bare, the Common Blues and Coppers wander forth from their usual haunts, and may be seen exploring the unwonted closes of lawns and gardens, in quest of the measure of moist coolness which they need. For though butterflies are such lovers of sunshine, their delicate lives cannot endure the absolute drought of the desert; and in the fieriest July weather the beautiful sight may often be seen of a thirsty cloud of Blues or Whites fluttering and settling on a wet patch where water has been spilt in the dusty roadway, or at the moist edge of a pool or running stream.

Deep in the southern oakwoods in July the great Purple Emperors hold court round the airy crests of the boughs, amid a silence so songless and solemn that the rustle of their own high, flashing wings may sometimes be heard in the sunshine above the murmur of omnipresent insect life that is the warp and woof of the stillness. There is indeed a majesty about the soaring, indifferent flight of this brilliant butterfly of the forest 


\section{BRITISH BUTTERFLIES}

solitudes which sets it apart on a regal pinnacle of distinction; only the Swallowtail can equal it in its conscious supremacy, its indifferent joy in spacious flight, and even the Swallowtail does not aspire to haunt for hours and days together only the loftiest, sky-fronting pinnacles of the oaks. As for the common reproach that the high-soaring Purple Emperor can be lured to earth by any carrion bait, provided it be corrupt and filthy enough, the accusation gains most of its force from the very unworthiness of its defamation. So far as it is true, it only deserves to be overlooked and unrecorded; and in point of fact, as little heed will commonly be paid by a court of Purple Emperors to any earth-born carrion that may defile the low shore of the wood beneath them as by the white clouds of heaven, afloat a little above.

As July passes into August, the whole fashion of nature takes a deeper and statelier range. The characteristic butterflies of latest summer and early autumn are those species of large size and rich depth of colour, of which the residue outsleep the dark interval of winter, to appear in the sunshine of the reviving year. Through August and September the deep red wings of the Peacocks, Tortoiseshells and their kin assemble in regal troops on the large flowers of later summer in the gardens, or on a few well-loved blossoms of the field or streamside, such as the tall hemp agrimony of 


\section{SOME ENGLISH BUTTERFLIES}

the reed beds, with its mauve, cottony plumes, the marjoram flower of the wide thyme-scented downs, and, most of all, on the pale purple, nodding scabious of the autumn pastures and dry slopes. The most splendid butterfly picture of all the year is one of these wide September hillsides of purple scabious blossom thronged and crowded with the floating and fanning wings of hundreds of butterflies of a dozen different species, varying in hue from cool pure white to the Red Admiral's scarlet-bordered jet, and from the fresh radiance of the Blues and Coppers to the glowing, patterned splendour of the Peacocks and Tortoiseshells and Painted Ladies. Here a blossom bows beneath the weight of a silky-bodied Brimstone, there a Clouded Yellow flashes its rich saffron against the dark, earthy under-side of the strangely fretted wings of a Comma. Dragonflies cruise and hover over the length of the hillside meadow, grasshoppers spring and chirr among the hair-poised blossoms, and a busy plebeian crowd of hive and bumble bees shoulder the butterflies rudely from their foothold upon the mauve button-like heads. Far and wide, where the individual blossoms of the scabious melt into a purple haze, the wings of this great company of butterflies shift and flash from moment to moment as they probethe honeyed flowers; one keen wing-profile, or brilliant eye-pattern, after another, catches the sight across the purple 


\section{BRITISH BUTTERFLIES}

shimmer of the field, and only rarely this absorbing insect concentration is broken for a moment as a brilliant Peacock or Red Admiral leaves its last blossom and skims down the length of the slope, to fall again to the nectar of the scabious bloom. The long days of mellow September sunshine will soon be over, and all the brilliant butterfly congregation scattered and dishevelled in the storm and rain; scarcely, in the rare interludes of October warmth and brightness, will the last Red Admirals be seen bickering with sluggish wasps and outcast and perishing drones over the opening clusters of the autumn ivy-blossom. Let us take farewell of the butterflies in the brilliant scabious meadow of September, as they fill it with their beauty and life, and not seek to follow them further into the darkness and cold. For indeed the tombs of such of them as die are as unknown as the sepulchre of Moses; and those that sleep out the long sleep into the spring we may hope to see again, heralding the elfin cycle of the butterflies' year under a new and a lengthening sun. 
THE BEE MIND 



\section{THE $\quad B E E \quad M I N \mathcal{D}$}

"Oh wonderful! Hath the All-Wise Creator plac'd such Wisdom, such Curious Art, such Fortitude and Foresight, so Polite a Government ... in Creatures so small as the Bees!"

-JOSEPH WARDER.

THERE is no familiarizing the honey bee. I never take the quilt off those glistening combs without a slight feeling of awe-it is as if one were opening the door of a chamber of mystery, stealing across the threshold into a place unknown, darkly wonderful. But the mysteries of the bee do not blind us to the plain fact that her intelligence runs in grooves; is of a strictly limited character. Of this there have been fresh illustrations during swarming time.

By the side of the overcrowded hive, out of which the old queen comes, with her great following, is often an empty hive, admirably suited to the new monarchy -or republic-for, despite tradition, it more nearly resembles a republic. Often, before the swarm comes forth, this vacant hive has been long and critically 


\section{BRITISH BUTTERFLIES}

examined by many bees, apparently explorers. Yet how seldom is it chosen and occupied without the guidance of the bee master! Instead of going into this hive, ranged and ready for them, the swarm will settle in a cluster on a tree or bush-by the river Lambourne, I found and all but trod on a swarm in a faggot -and will finally establish themselves, if they are not taken charge of, in the roof of a house or the hollow of a tree.

But only introduce them to the beehive which-in vain - their explorers have examined, and which they themselves have passed a hundred times a day, and they will joyously run up the alighting board, jostle in at the entrance, and then and there take possession of the very spot that they need for founding their State in.

If their intelligence had anything like affinity to human reasoning power, surely the swarm, on emerging with their queen, would go straight into that empty hive with its hanging row of bar-frames, each supporting a sheet of wax ready to work out into cells. Instead, the bees will waste a precious day or more at the height of the honey flow, examining, re-examining, some crevices about a wall or roof, which are not the least good to them. I have seen it mentioned as a sign of the bee's wisdom that the swarm coming forth will often fly several miles away from their old home- 


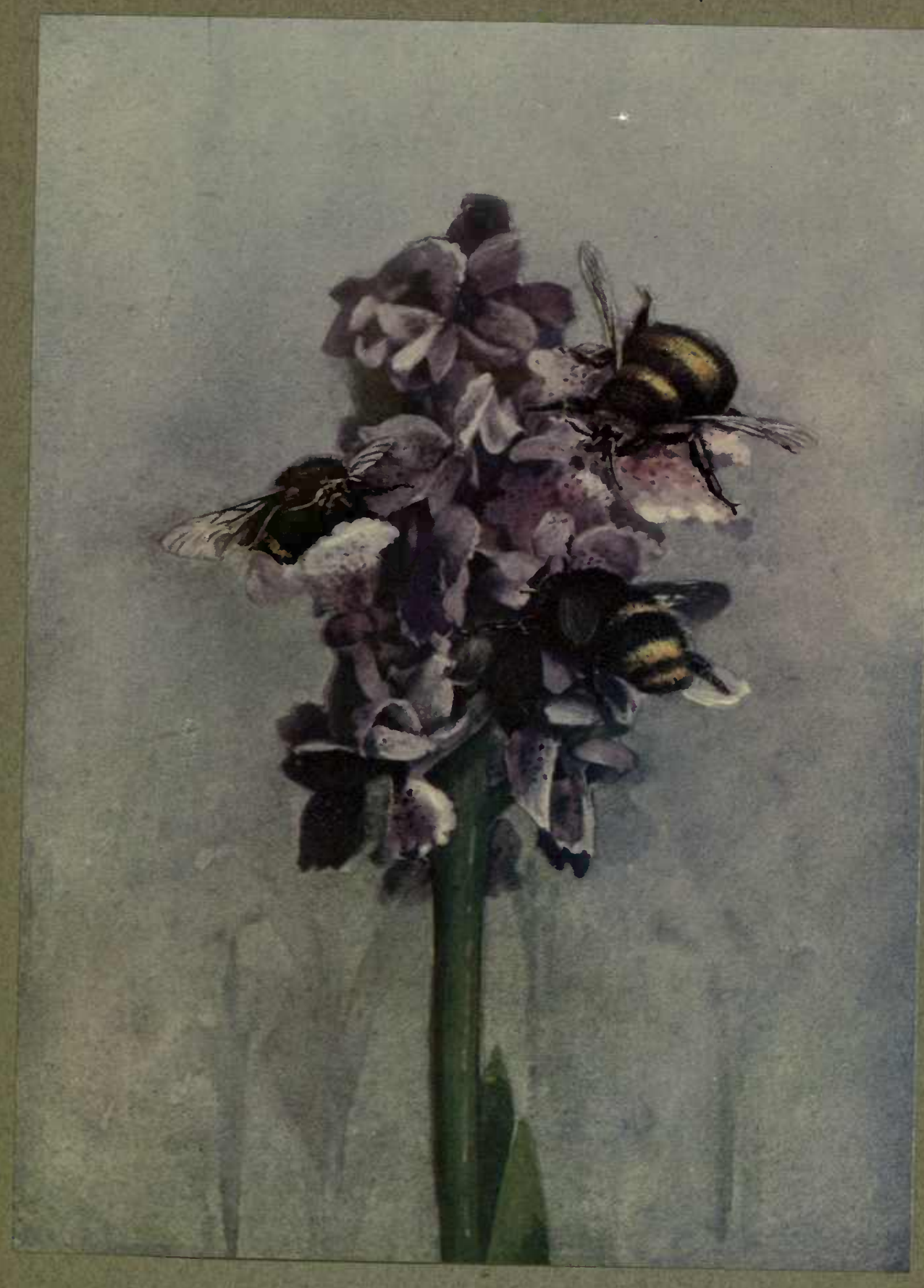

BEES.

From a photograph by

F. Martin Duncan, F.R.P.S. 


\section{THE BEE MIND}

as proof that the bee does not wish to overcrowd a neighbourhood. But, if so, why, when the swarm is shaken down in the cool of the evening on a white sheet outside the empty hive, do the bees promptly crowd up, with all the music of satisfaction, carrying their queen with them, and take possession?

No-the bee intelligence is strictly circumscribed. What we term "reasoning power" does not seem to exist among bees. The arrangement, the order of their State is marvellously beautiful. The spirit of the hive is beyond praise in its devotion, discipline, endurance, fiery patriotism. But here end the virtues of the bee. Compared with those qualities her intellect is beneath contempt. Her machinery of mind cannot move outside the deep worn grooves of habit, which I suppose were slowly made-geologically slow-in the unreckoned thousands (or should it be millions?) of years of her unknown history-for one cannot doubt that this is one of the most ancient civilizations in the world to-day-it may even be the most ancient. 

GHOST MOTH EVENINGS 



\section{III}

\section{GHOST MOTH EVENINGS}

"The desire of the moth for the star, Of the night for the morrow; The devotion to something afar From the sphere of our sorrow."

-SHELley.

I FIND the difficulty at midsummer is not to avoid repeating one's observations of living things, and of sky, sea, and landscapes; rather, it is so hard to fix the thought and eye on the same things in successive Junes. No risk, indeed, of going over old ground in detail at this season! The subject-matter of Nature is so inexhaustible, the time so tantalizingly little in which to examine and enjoy it, that the tendency is to turn here and there, to press on always to a fresh thing each June, instead of concentrating on what we attended to this time last year. Out of the great treasuries of these wild-rose days, treasuries of song, scent, colour, and life manifested in most exquisite forms, we are always tempted to choose some new thing. But there are certain June episodes that, once noticed, 


\section{BRITISH BUTTERFLIES}

will be looked for season after season with lively interest. One is the dance at dusk of the ghost moth. Last year this was kept up in the tranquil evenings of the second fortnight in June, and it continued well into July.

The dance is now again at its height in the meadows. It has taken place of late on evenings that closely recall those of last June: the same calm, the same scented breath of the evening just before hay harvest-the partridge plaint-the crooning of night-jars-the peepy notes of the latest song thrush at a few minutes after nine o'clock; only a change in planets, Venus burning in the tinted west instead of the taper of Mars in the blue.

The clock of the moths, like that of the birds, must surely have minute, if not second, hands. After watching and waiting for the ghost moths' appearance on two successive evenings, we may on the third evening reckon almost to a minute-if the weather is of the same character-when they will come whirring out of the long, thick meadow grasses. At ten minutes past nine, I found most of the ghost moths oscillating in the meadow. Next night at nine o'clock not a ghost moth was to be seen, though here and there its relative and frequent companions in the meadows, the common swift moth, was whizzing through the grasses. But ten minutes later a male ghost moth came up; there 


\section{GHOST MOTH EVENINGS}

was an interval of a minute or so, and then, all at once, the corner of the field was full of ghost moths, satinwhite male and brown female. I could count nearly a score on a small patch of ground a dozen square yards in extent, and could hear others impatiently whirring deep down in the tangled grasses as they tried to rise on the wing.

One evening the dance had ended at half-past nine. Every moth had dropped into the grass depths and run a little way up a stem, and there it would be hanging till after nine o'clock next evening-unless by any chance the ghost moths dance again in the dusk of the morning - a twenty-four hour rest. My impression is-though I am not sure-that the ghost moths' dance only takes place once in each twenty-four hours, and lasts each time less than an hour.

As they dance over the meadow grasses, there seems little or no rivalry among the male moths; at most, they will now and again brush each other lightly; it is here as if each were far too engrossed in his own movements to trouble about neighbours or rivals. But of late I have noticed a curious variant of the usual ghost moth dance over the grass heads. At the corner of the field is a small lime tree, and round this a dozen males were playing one evening. Instead of swinging from side to side, as one might expect, they here rose up and down, and whisked in and out among the leaves"; 


\section{BRITISH BUTTERFLIES}

now a moth would be near the top of the tree, and now he would be down within two yards or so of the ground; this was more like the rise and drop of the winter gnats in column than the meadow swinging of the ghost moth.

But the oddest feature in this tree variation was the attention two Imale moths would pay each other. Whether it were rivalry, or whether insect sport and game, I could not say. Two moths would pursue each other-apparently now one, now the other, being pursuer - up and down, and even in and out among the outer leaves of the tree. They would lose each other in these chases, but find each other-actually distinguish each other among several ghost mothsand give chase again in a few moments. Constantly they would collide, brush against or tap one another, and at each tap the lovely gloss of the wings, perhaps the fine brown fur of the tippet, too, must have lost a little.

As to the female ghost moths, I did not see them engaging in this dainty play, though several were hovering over the grasses. The female's movements slightly differ from the male's. From what I have seen, I cannot think she is attracted by the liveliest male dancer or the largest-in size the males differ muchor the most satiny, exacting or nice in her choice of a lover; and more, I now have some doubts whether the male seeks and finds his lady by eyesight at all. 


\section{GHOST MOTH EVENINGS}

Another time I hope to touch on this theme, obscure, but deeply interesting. My attention was first drawn to it by a correspondent at Loughborough last summer. If eyesight play no great part in this extraordinary performance, why all the beauty show ? 



\section{THE RAILWAY EMBANKMENT}





\section{IV}

\section{THE RAILWAY EMBANKMENT}

"With her a sweet companion came, One alway smiling-'Peace !' she said."

-William H. Davies.

LANDSCAPES and gardens we do not want to have all to ourselves ; companions may often help us to their full enjoyment. But to watch wild life in the finer line and shade, freedom from intrusion is a great thing. The unsympathetic stranger is embarrassing. Figures and voices of wayfarers, even of toilers in the field or wood-much more of holiday-makers-should belong to the distance, be embraced in a kind of bird's-eye view. If, however, the occasional passer-by does not actually encroach on our preserve, is unconscious even of our existence, he may be almost welcome. To a hermit behind a hedge, the footfall of a passer-by can be quite agreeable : it may add something to the triumph of solitude to feel that we are in such complete seclusion that even a wayfarer a few yards off goes by without suspecting our presence. 


\section{BRITISH BUTTERFLIES}

It is this seclusion that often makes the lower part of the railway embankment, screened by a splendid hawthorn hedge, such an excellent spot in summer. There are stiles and footpaths close to, perhaps alongside, these hedges, but the railway ground remains absolutely private. The trains above take nothing from the privacy of the place : lying on the slope or walking among the June grass and ox-eye daisies by the hedgeside, one sees hardly anything of them. Their noise does not distress us; the grand thunder and the shake of trains at these close quarters is good rather than otherwise. I doubt whether it jars even on sensitive nerves. Besides, we can grow accustomed to this sound so soon that, after a short experience, train after train may roar by without our noticing them. It may be the same with wild animals. The pipit or yellow-hammer perched on the telegraph wire does not stir for the fastest, loudest express. I have seen the beautiful little merlin equally unconcerned. Is he conscious, indeed, of its passing ?

I have heard that nightingales haunting wooded places by railway lines will sing persistently all night, and I seem to have noticed how long and choicely the railway nightingales sing in Kent. A friend says he thinks it is because they cannot sleep through the noise of the goods trains crashing and thundering all night. Noise is a stimulant to song with birds, and I have 


\section{THE RAILWAY EMBANKMENT}

suggested that it may be the river which makes the sedge warbler so songful by night and day. But it is just worth considering as a theory, not more.

The railway embankment is as favoured by butterflies and day-flying moths this June as I found it last year. The lovely little heath moth has been out in numbers since the beginning of the month. It has none of the brave apparel of the wood tiger and the cinnabar moths which also fly by day along the slope, being a greyish little thing, flaccid almost as the snowwhite plume moth, but far warier than he. The pattern on the upper wings of the heath, yellowish with wavy brown stripes, is neat as neat can be: to describe it truly you want language fine and pointed as an etching pen, a tongue of diminutives.

The flight of the heath moth is not so weak as one might expect from such limp-looking wings and body, but it is highly erratic, like that of many moths and butterflies with thin bodies and wings that seem as if they had no muscles to work them. Like the "carpet" moths and notably the orange-tip and the white butterflies, the heath moth zigzags along. The movements, on the wing, of an orange-tip butterfly and a small bird-say a chaffinch-or a larger one-say a green woodpecker-are so entirely unlike that one may wonder whether the same principles are here at work. The bird seems to bound through the air in a clean 


\section{BRITISH BUTTERFLIES}

curve, the butterfly apparently can only go forward by quick little flutterings to right and left : to make progress the orange-tip or cabbage white must ceaselessly bob from side to side. With the butterfly we see nothing of the springs, the rise and fall of the body in the air, the clean, distinct closing of the wings between the leaps.

The heath moth and the orange-tip butterfly get along somehow, can fly against a little breeze, as with it, but there really seems-and here, of course, is deception-to be no more machinery about their flight than about that of a flimsy scrap of paper upheld and buffeted about by gusts of wind. This is not so with all moths and butterflies, nor with beetles on the wing, many flying clean and straight.

Another curious style of flight is to be seen on the railway slope. Mother Shipton's likeness is out, and when she flies her wings appear half open, half closed. It is the same exactly with several of the skipper butterflies, and with the much larger grayling butterfly.

But to my eyes the butterfly gem of the railway slope in early June is the tiniest of them all. This is the Bedford blue, which is to butterflies what the golden crowned wren is to birds. Last year I saw him out in May; this year, early in June. Though so minute, he is a butterfly every line of him-you must measure him by lines not inches-far more so than the skippers, 


\section{THE RAILWAY EMBANKMENT}

which only pass muster as butterflies because they have, for hall-mark, the club at the tip of the antennæ or horn, which no moth can show. The Bedford blue is not brightly coloured like several of! his larger relatives-has just a little dust of blue on a brownish ground, and his wings on the under-side are ash grey with a thought of blue about them. But they are cut to a dainty shape, and fringed with white or greyI cannot make up my mind which, watching him sunning himself on a grass blade.

Nimble on the wing, alert, so spruce in his whole turnout, this blue is a fascinating little thing to see. I have not yet found him on his bed, but I suspect he sleeps, like the common blue, head downward and upper wings laid back so that only the tips show above the under wings. Probably he assimilates with environment then more closely than the common blue, Alexis, or is less noticeable not only through his smaller figure, but through the spots-held in tiny rings-on the underside being less striking than those of his big cousin. 



\section{BUTTERFLIES IN BED}





\section{V \\ BUTTERFLIES IN BED \\ "On the Infinitely Little."}

THE grassy, heathery clearing in the Surrey birch wood has been the playground of butterflies for weeks past. A few battered meadow-brown butterflies of July, their poor wings worn as jagged as those of the comma, linger on, but their junketings are nearly over. The Ringlet and the Large Heath butterflies succeeded them before the end of the month, and occupy the bramblebushes by day and night. Last year, though I pryed closely in their woodland haunts in another districtamong hazel, oak, and brake fern-I could find very few Large Heath butterflies settled for the night. Lately I have discovered many on the bramble-bushes in the birch wood. Like Meadow Brown, Grayling, and other butterflies, the Large Heath, settling for the evening and night, always draws down its folded upper wings, so that the conspicuous spot or eye on the back of them is hid. One effect of this is to make 


\section{BRITISH BUTTERFLIES}

the Large Heath a trifle obscurer at rest on the bramble leaf than it would be with the wing up.

But I do not believe the real explanation or object of this withdrawal of the "eye" from public view is protection of the butterfly from enemies of prey by inconspicuity, or by assimilation to surroundings (gross words to use of a sylph like the Large Heath! but I know not how to avoid them here). My notion is that there is no night enemy that need be cheated -if it could be cheated thus. Protection of butterfly beauty against weather-this, I think, is the meaning of the withdrawn "eye." I admit that, if you set out to look for butterflies at rest and matching their environment, you will find them. The Small Skipper butterfly sleeping on the spear-thistle looked greenygrey, I noticed, matching his perch. We watched a Meadow Brown, disturbed by large raindrops, perch on a birch twig, and put away his " eye," and we agreed he would pass for a dead leaf. But other Small Skippers, small and large kinds, slept on seeding grass heads and the matching was not close; and, after all, is a Meadow Brown so very like a dead birch leaf when you come to think of it ?

More striking was the case of the Golden Y moth, the pretty insect which is out in moist places in the birch wood, and flies often by day. I watched one settle on the trunk of a birch tree. It has some dark 


\section{BUTTERFLIES IN BED}

fluff or fur, that stands out like a hump or excrescence on the back, which really does remind one of the dark, rough cork of the birch trunk near the ground. If this were the usual resting-place of Golden $\mathrm{Y}$, it would seem very like a matching precaution; but there is no evidence to speak of that Golden $\mathrm{Y}$ moths prefer for sleeping quarters the rough, corky trunk of the birches; I think my moth settled thereon by chance. I found him first amid the copse grasses and crossleaved heather, and I found another Golden Y moth next day resting off the birch trunk in the undercover of the wood.

In the lane end are still a few Silver-spotted Blue butterflies, sucking the bird's-foot trefoil and the bramble-blossoms: a month ago there were dozens. The Silver-spotted, with lilac-blue wings and their clear fringe of white, is quite as lovely a little flyer as the Common Blue butterfly; indeed, in minutiæ-and perhaps because he is not so common !-I think him the choicer of the two. Of the sleeping quarters and habits of this gay beauty I know little yet; one or two I found at rest slept head upward, not like the Common Blue their near relative head downward; but perhaps this was exceptional, due to some chance disturbance -I can hardly imagine the sleeping habits of the Common Blue differ from those of his first cousin.

Nobody could doubt that to watch butterflies and 


\section{BRITISH BUTTERFLIES}

moths is to train the eye to beauty on a scale of exquisite, if tiny, perfection; this is absolutely plain"to every seeing, thinking man. But a study of the habits, minutiæ of minutiæ, of such little things-how can this avail human beings ? it may be asked. Is not the man who does it rather like Browning's grammarian, who fiddled away his life on Greek enclitics and particles, holding forth on them till he was dead from his feet to his waist ? Would it not be wiser to aim at the million and chance missing the unit ? Yes, but in these units secrets of life-secrets of whence, whither, whyare concentrated. In the end we may know ourselves through a blue butterfly. Only we must watch and record, utterly careless of any theory; if this butterfly's nightdress does not mimic its surroundings, we must accept the fact, careless of theory. Theory is a feather-weight set in the scale against truth, a matter of supreme unconcern. 


\section{PEARL SKIPPERS}





\section{PEARL SKIPPERS}

"The fly buzz'd up in the heat."

Punctual almost to a day I found my lovely little pearl skippers at their prime on the hillside where I watched them last August. Roughly, pearl skipper is large skipper, plus a set of natty, four-sided figures tessellated work, that are imprinted on the upper and under sides of his wings. These light-coloured marks -had the naming of the butterfly been mine, I should not have suggested pearls-are his chief distinction, but I fancy he also differs slightly from the large skipper in size and in one or two finer details. I have only seen him alive-so alive too! - on his native down; never in the cork-lined box, nor wish to ; and he is not very easy to get quite close to ; but, judging by what I have seen of him on a blossom about a yard off, his horns are not ringed with white, and he wants the faint flush of purple on the lower wings which his cousin has. 


\section{BRITISH BUTTERFLIES}

$\mathrm{He}$ is a gem, though he does not flash with gemmy colours; is of the live bijoutry of nature. He flies in the fizzling heat of an out and out August day; whips from flower to flower, mixing the nectar of birdsfoot trefoil with the nectar of hawk-bit; and, after a few sips, will settle on the ground or on a leaf, draw-to those muscular little wings, clean horns with legs, and unroll and clean his trunk too.

$\mathrm{He}$ is scrupulous in this as are most butterflies. Comfort, not cleanliness for its own virtuous sake, and not fastidiousness or nicety, is the secret of all this wiping of trunk and horns, and perhaps of face, too, after a course of sweetmeats. All the same, it is a very pretty thing to see the pearl skipper purify himself between the feasts. Then, whisk !-he is up and off, chasing or chased by another pearl skipper at such a hot pace that the eye cannot always follow the combatants or lovers, whichever they be.

Pearl skipper and large skipper, which we might call blood relations, first cousins even-though, unlike first cousins in human relationship, they are not suffered by Nature to intermarry-have come from some common ancestor-have evolved, if this term says more. I cannot understand how any one can doubt that these two skippers, that all the skippers, were at the start one skipper; or the blue butterflies or arguses one blue butterfly or one argus ; that is to say, 


\section{PEARL SKIPPERS}

one kind of skipper, argus or blue. That these forms of life began separately and independently of each other is unthinkable.

No; the pearl skipper and the large skipper were evolved and distinguished by gradual creation. But what exactly gave the one his pearls and denied him white rings on the antennæ or horns; what gave the other his white rings but denied him the pearls? Here is a riddle as unguessed as that of the making of Antares and Arcturus, the great ruby and amber stars of these August evenings. Half the secrets of life and evolution lie in epitome in this dot of a butterfly. Common sense tells us the skippers evolved through a common ancestor. But darkness follows on this glimmer of light. Why and how pearls for the pearl skipper ? Nothing in food, habit of life, or haunt gives the clue. Take the pearl skipper to pieces, put him under the most powerful microscope, and I doubt whether his physiology will help you forward in the least. Here theory comes in with the general principle by which pearl skipper took one branch road, larger skipper another, on the map of life. But, unfortunately, it cannot offer a tittle of evidence as to this particular case of pearls and rings; and it leaves one unsatisfied. The pearl skipper's path of evolution and the purpose served by his travelling this path are darkly hid away. 

ANAXX IMPERATOR

53 



\section{VII}

\section{ANAX IMPERATOR}

"He dried his wings; like gauze they grew.

A living flash of light he flew."

- Lord Tennyson.

THE peopling with wild life of woods and waters formed artificially is to me often a mysterious work. Flowers, insects, sometimes even fishes, will appear on the scene though hitherto they have been unknown in the district. Make a pond or lake, using for your water supply only the hidden springs that make the ground round about soppy; even confine your efforts to catching the moisture in the air by means of straw and clay and a shallow basin scooped out on some common or among the hills; and before long Nature will give it forms of life strange to the place-insect life especially, above water and below.

There is a shallow artificial pond, a few acres in extent, among the pine and birch woods, which is good to visit in July. It does not offer the refreshment of 


\section{BRITISH BUTTERFLIES}

the clear, running stream. It is half choked now with American pond-weed and with native water flora, so that the waterfowl can only paddle about slowly. But, through the sheltered nature of the place, the face of the lake is glassy still ; it mirrors the woods and the sky to perfection on a bright day.

Each tree round the lake, with great ceiling of blue and grey above, is doubled to a detail in a world below water; so that if, lying by the lake, I wish to study the beauty of form and colour about the trees or clouds, it can be done without raising the eyes. The floating leaves of the water plants seem not in the least to interfere with the reflection. All that is needed for faithful representation of the sky and wood here is a glossy smooth surface and a bright sun at the back of the watcher.

When the sun is out, the dragon of the wooded lake is on the wing. As he flies to and fro across the centre of the lake, sometimes settling on the rhododendron islet in the middle, he may give one the idea of some diaphanous bird, a bird of fairyland. His crystalline wings, wafer-thin, flash in the sun, and at fifty, even a hundred yards distance, we can get glimpses of the bright blue of his body. This splendour is the Emperor of English dragon-flies, Anax imperator.

He looks all sheen and pride; and, for flight, it is as if he enjoyed not so much mastery over the air as 56 


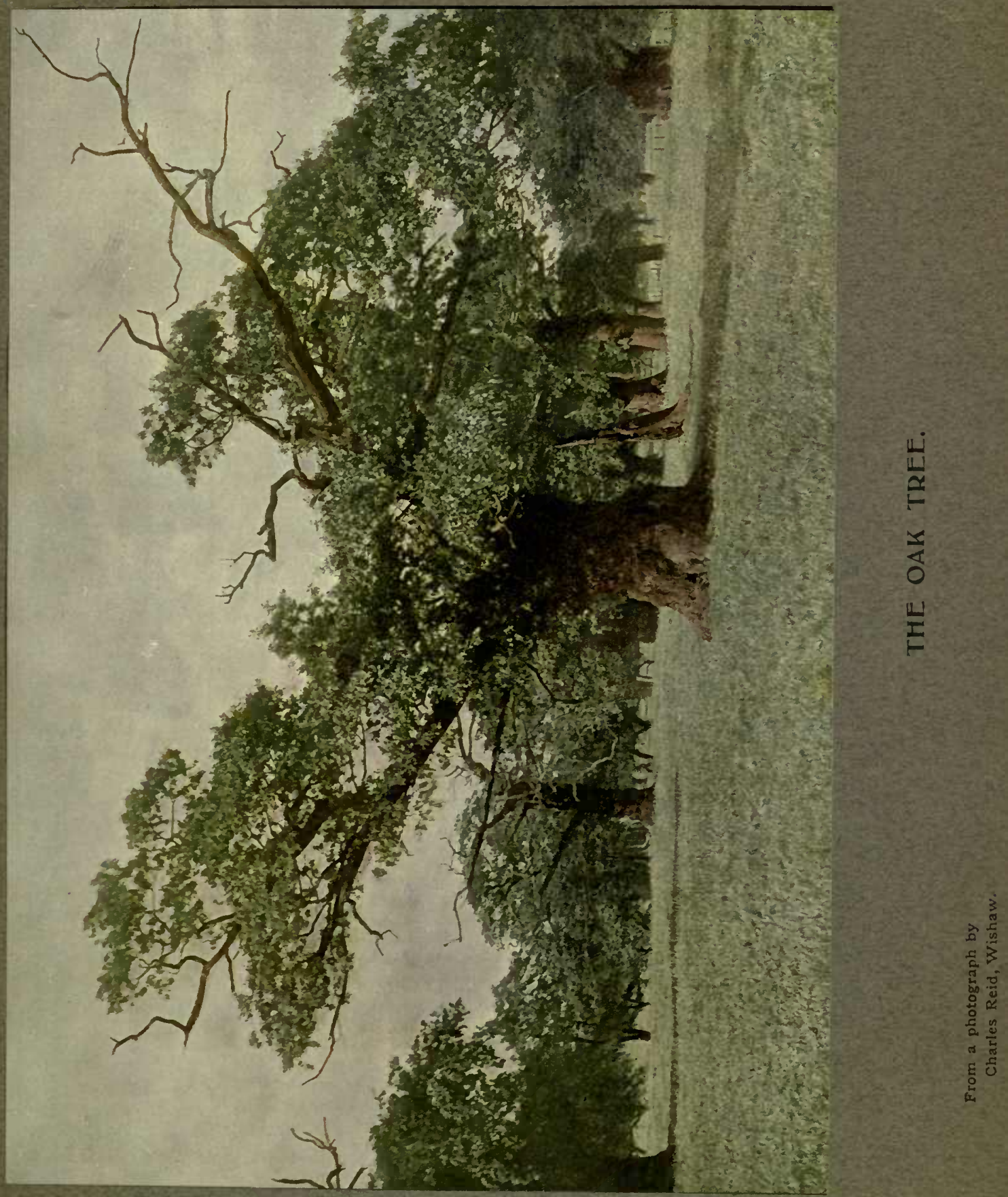




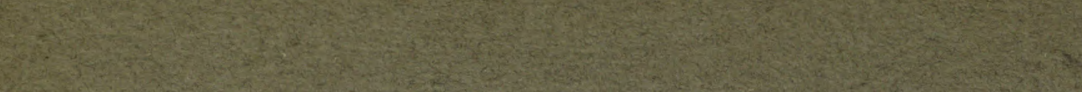

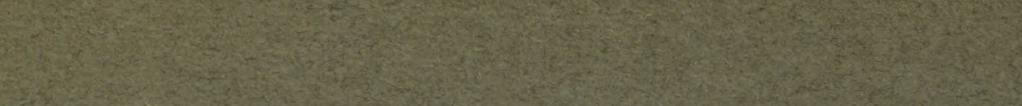
$\operatorname{lin}^{2}+\sin ^{2}$

(19)

is:

(1)
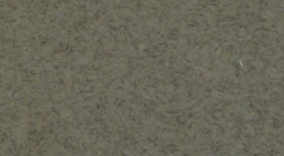

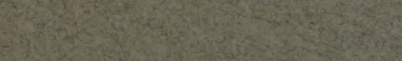

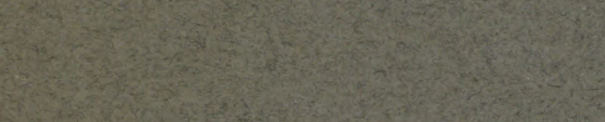




\section{ANAX IMPERATOR}

commerce with it-as we can fancy the red hawk does.

Anax is imperious, " bears with no rival near the throne." The lake just now holds two emperors at least, besides, perhaps, their consorts, whom I have not noticed. When one emperor invades the other's realm, a fiery, running duel begins. Up and down the outraged tyrant pursues the invader, both darting, skimming just above the lake with their arrowy straightness of aim. Anax has not, I should say, the swiftness of some of the moths, of the humming-bird hawk moth, but his is superlative flight not the less, proud and beautiful as that of any winged thing.

Not only the lake in the woods, but the rough, boggy patches about it, even the dry, rising ground, are now full of a dragon-fly of quite another character. This is Puella, the little girl, a slip of a thing, with-compared to the emperor's-a weak flight, but not a dancing or bobbing flight like the demoiselle's. The little girl's wings are of the usual crystalline texture, and the body is pure bright blue, with regular rings of black. You see this choice fly flitting over all parts of the lake when the sun is out, constantly settling on the leaves of the water-lilies and any scrap of green or brown-green that thrusts up to the air.

On a very hot afternoon the place has a tropical look and atmosphere; an effect produced by these 


\section{BRITISH BUTTERFLIES}

glittering flies, dragons of the air, and the burning sky blue mirrored in the dead still lake. But if a thrush sang by the lake, on such a day, the whole might be homely English at once. The thrush is our national bird. 
THE SPHINX MOTH 



\title{
VIII
}

\section{THE SPHINX MOTH}

\author{
"The beam-like ephemeris, \\ Whose path is the lightning's."
}

I HAVE just seen the sphinx moth bravely on the wing and feeding in the squalls of wind and rain! Though my charming little friend will sometimes fly on summer evenings about sundown, I have always imagined that he was a worshipper of bright hours and warmth. I thought him a sound sleeper, like a butterfly, during rude weather. Yet here he came on the wing, brisk as could be, on a dark, rough autumn day. He zigzagged from blossom to blossom-red and pink geraniums - and, buffeted by the wind and beaten on by the rain, he still held himself aloft, and plunged his trunk into the nectaries, seeking their sweetmeats.

Sometimes the wind would toss him from the blossom ere he could poise himself close enough to plunge 


\section{BRITISH BUTTERFLIES}

trunk down nectary; but defeated once or twice, he would return and in the end succeed.

Whilst this humming-bird hawk moth hovers, its wings appear to whir not at right angles to its bodyI should say they may be at an angle of $45 \mathrm{deg}$. or so, and away from the head. Often whilst drawing the sweets from a blossom, the insect is hung in the air, touching nothing with its legs, which are laid back close to the body, like those of a sea-gull in flight. But, look very closely, and you will see that now and then when the hawk moth appears to be hanging in the air it is really resting-so lightly, though, as not to crumple a petal ! - on the flower, with its thin little grey legs.

Yet, resting so, it keeps whirring its wings as if it were hanging without support.

One thing I notice in my sphinx which shows it not so infallible of eye as it might be. It will sometimes visit dead blossoms of plants round which it is hovering. True, it discovers instantly that they are dead, and is gone in a flash to a fresh blossom. Still, were its sight extremely powerful, would it waste one beat of the lightning wing on a visit of inquiry to a flower that was spent and almost colourless? I think not The sphinx is not the only sweet-seeker that makes a momentary mistake of the kind. The cumbrous droning humble bee has an eye for colour, but has it 


\section{THE SPHINX MOTH}

one for form ? It came to the handle of my garden roller when this was new and painted with gaudy colours. It took these rings of coarse colour for blossoms-to which they bore no likeness. The bee or butterfly appears to be only infallible of eye when it is close to the object, almost touching. At a little distance, perhaps it sees just a blob of colour ; it must come very near to make out the exact form and texture of the thing observed.

To read the flowers aright, it must have its face pressed close to the petals, as a short-sighted man must have his face pressed to the book. Once at close quarters, however, the insect sight is very powerful -it has every detail under microscope:

Another thing about the little sphinx moth is the quickness with which it discovers whether a blossom has honey or not-once it is up to the flower and poised: That fine feeler, the trunk, is out of the nectary in the flash of a second if there is no honey.

By the way, how does the sphinx carry its trunk when it is honey-seeking and roving from blossom to blossom ? Well, when the flowers are very close together, when they belong to one bed or patch, the sphinx does not neatly roll up the trunk and pack it away; nor is the trunk carried about quite unrolled. A sort of compromise is more convenient. The trunk is 


\section{BRITISH BUTTERFLIES}

kept out, quite loosely rolled up. Thus it does not impede the movements of the moth, and at the same time is ready to straighten out and plunge into the nectary of the flower. 


\section{FIELD NOTES ON SOME ENGLISH BUTTERFLIES}





\section{IX}

\section{FIELD NOTES ON SOME ENGLISH BUTTERFLIES}

"There is a difference between a grub and a butterfly; yet your butterfly was a grub."-SHAKESPEARE.

Among the white butterflies that flit about the meadows and even the grassy margins of the high roads, in May and June, will be noticed some that have the outer portions of the forewings orange-coloured. These are the males of the orange-tip, but the females are without the orange patch. The undersides of the hind-wings in both sexes are marked with greenish, and when the insects alight on the white flower-heads of the beaked parsley, and various other early blooming Umbelliferce, the wings are so arranged that only this surface and just the extreme blackish tips of the forewings can be seen. Unless we carefully note the exact spot upon which the butterfly pitched, we shall have some trouble in detecting it on its resting-place. The markings of the underside so beautifully correspond with the insect's 


\section{BRITISH BUTTERFLIES}

surroundings that, although we may really be looking at it, we shall fail to recognize it as a butterfly. After a little practice, however, the eye becomes accustomed to the work required of it, and will locate the butterflies easily enough. The orange-tip delights in sunshine, and few will be seen on the wing on dull days, but they may then be sought for among the blossoms. If eggs or caterpillars are desired, the former may be obtained by searching the flower-heads of the lady's smock or of the garlic-mustard; the latter on the seed-pods of the same plants. Or a female butterfly may be captured, and afterwards enclosed with a spray or two of water-cress in a receptacle that admits both air and sunshine. She will deposit eggs, and the caterpillars that hatch from these will feed upon the watercress if this is kept in a suitable condition, which may be done by putting the stems of the cress in damp sand. Both sand and food-plant will have to be renewed from time to time, and if the cress can be supplied in flower it will be more to the liking of the caterpillars, as well as to the butterfly when she is egg-laying.

Whether undertaken with a view to deeper study, or merely as a practical life-history lesson, the experiment of rearing a butterfly from its first stage as an egg, through the subsequent forms of caterpillar and chrysalis to perfect insect, is certain to be highly interesting. 


\section{FIELD NOTES ON BUTTERFLIES}

Eggs of the large or the small white butterflies, for example, are very insignificant objects that may often be seen in dozens when looked for. They will be found standing upright on either surface of a leaf of the familiar cabbage growing in the garden. Place one of these eggs, which are more or less skittle-shaped, under the microscope, and it will be seen to have several ribs extending from the blunt apex to the base, and a number of finer lines around its circumference. Probably when first noticed the eggs may be greenish or yellowish-green, but if kept under observation for a few days they will be found to turn greyish. The last change in colour indicates that the caterpillars will soon emerge from the eggshell. To enable it to make its début the young caterpillar bites through the shoulder of the egg, and before it emerges therefrom it has eaten a large portion of the shell. It is of course exceedingly small at first, and very unlike what it will become when full-grown. Its existence as a caterpillar is of comparative short duration; but this stage is nevertheless a most important one in a butterfly's career, and full of stirring episodes. Not only has it to pass through the ordeal of changing its skin on several occasions, but enemies, especially those in the shape of parasitical flies, are ever on the watch to destroy it. The flies deposit their eggs on the back of the caterpillar, and the tiny grubs that hatch from these enter 


\section{BRITISH BUTTERFLIES}

its body and therein establish themselves as nonpaying guests. Caterpillars so commandeered often succeed in attaining the chrysalis stage, but this probably only happens when the parasites are later than their host in arriving at maturity. Although a large, sometimes very large, percentage of caterpillars are "ichneumoned," some certainly do escape the attention of these undesirables and other foes, and therefore reach the chrysalis stage in a healthy condition. From such chrysalides butterflies emerge in due course, the whole period occupied in passing from egg to butterfly not much exceeding six weeks in the summer-time.

Some butterflies require the whole of twelve months to effect the changes from egg to perfect insect, whilst of others there will be three generations during the year. Hibernating species such as the brimstone and tortoiseshells are in the butterfly state for at least six months, but they are in a dormant condition during the greater part of that time. Even so their active life is longer than that of the small copper, of which there are three flights of butterflies in the year. The duration of the caterpillar life is also a variable quantity. In some kinds this stage is protracted over several months, whilst in others it lasts only a few weeks. Then as regards the chrysalis, some kinds remain much longer in this stage than others.

Down yonder lane, on the sunny side of the old barn, 


\section{FIELD NOTES ON BUTTERFLIES}

there is a fine patch of nettles, and on these we shall most likely find a colony of spiny caterpillars busily engaged in devouring the leafage, or perhaps they may be sunning themselves on the web of silk which is the result of their co-operative industry. This web may be regarded as the common hall of the colony, in or upon which they congregate for moulting, basking, or other purposes. If the caterpillars we find are black, speckled with minute white dots, they will produce the peacock butterfly; or if they are greenish-grey or ochreous grey, with paler lines along the back and sides, then the small tortoiseshell may be expected to result from them. When full-grown such caterpillars are rather formidable-looking creatures, clad as they are in spiky armour. They may, however, be handled with impunity, as the apparently sharp point of the spines yield to the touch and are incapable of penetrating the skin. The repellant character of this style of caterpillar clothing is effective enough no doubt in the case of birds. It is, however, not efficient in securing immunity from the attack of parasitic flies.

Now we will look at those thistles growing on the common where a painted lady butterfly was seen on the wing a week or two ago. Yes ! here are signs of a caterpillar having fed upon this plant. The fleshy parts of these leaves are completely demolished, but they still remain fastened together by silken threads. A little 


\section{BRITISH BUTTERFLIES}

lower down the plant there is a freshly constructed habitation, and in it the maker will be found. Ah! there he is, sure enough. Be careful in opening the retreat, for the spines of the thistle are sharp, although those of the caterpillar are not. In general appearance this caterpillar is not very different to that of the tortoiseshell seen on the nettle, but it is stouter.

The painted lady is closely related to the peacock and the tortoise shells, but, unlike those species, it is always solitary in the caterpillar state. The eggs are laid singly on leaves of thistle, and occasionally on burdock or mallow. The caterpillar just interviewed was almost certainly from an egg laid by a female butterfly that had passed through its own early stages in some far-distant country, possibly in Africa. Almost incredible it may seem that butterflies can travel great distances, but it has been pretty clearly established that they do so.

A good many species of butterflies, and a larger number of moths, are well known to be migratory, and quite a respectable contingent of these find their way to this country. Among immigrant butterflies that arrive here most regularly is the painted lady just adverted to, next in order come the clouded yellow and its cousin the pale clouded yellow. The Camberwell beauty pays us very irregular visits, but does not reproduce its kind in Great Britain as the other species 


\section{FIELD NOTES ON BUTTERFLIES}

mentioned are known to do. In North America this butterfly, there known as the mourning cloak, is very common. In Europe it seems to be most at home in Scandinavia and Germany, but it occurs in many other countries, although its appearance in some parts of the continent is almost as uncertain as in our own islands. If eggs are obtained from abroad the butterflies can be reared quite easily. The caterpillars, which live together in companies, will eat the foliage of various willows, poplars, and the birch. The specimens that come to us generally arrive in the autumn, and as it is the habit of this species to pass the winter as a butterfly and to pair and lay eggs in the following spring, the chance of these things taking place in this country are very small. There is very little doubt that specimens do occasionally hibernate here, but these are pretty sure to fall to the net of some collector when they come forth in the spring. Even if they escaped capture the odds would be against the sexes meeting with each other. The brambles alongside the quiet lanes are in full flower, and as we pass quite a cloud of meadow brown butterflies fly up and flutter away. Stand perfectly still awhile and they will return to feast again on the nectar of the blossom which is so attractive to them. Although when on the wing these butterflies appear to be all alike, dingy brown and uninteresting, this method of observation will enable us to note 


\section{BRITISH BUTTERFLIES}

that there is much diversity among them. One or two are now seen to be almost black in colour and velvety in texture. These are males, and have just recently emerged from the chrysalis. The female of this butterfly are always more highly adorned with orange, and in some of them this colour is spread over a large portion of the wings. In some respects the very fresh male meadow browns are similar to the ringlet, which is sometimes almost as numerous on the brambleblossoms. The former butterfly may however be readily distinguished by the orange ring around the white-eyed black spot at the tip of the forewing. Presently the butterflies close their wings over heir backs, and then the undersides are exposed to view. We now see that the ringlet has the wings ornamented with eight yellowish ringed black spots, and it is from these markings that the insect receives its name.

Leaving the lane, a pathway is taken which leads through cornfields to the downs. Having passed the fields we come upon a broad strip of rough sloping ground with a tall thick hedge separating it from the downs proper. Here are butterflies in abundance, but the majority of them are white or creamy white, with blackish markings. These are the marbled whites, and it will be noted that our presence in their midst does not greatly alarm them. As we approach they 


\section{FIELD NOTES ON BUTTERFLIES}

take wing, but only to flap lazily away a short distance If there happens to be a strong breeze they may be wafted in the direction of the cornfields, but they. will return to their headquarters ere long. Here, too, we shall probably see a few specimens of the chalk hill blue; but as we ascend the down on the other side of the hedge these butterflies will be more in evidence. The males are blue, but the females are brown and less active on the wing than the males, and have important maternal duties to attend to, so that they are more often observed crawling about among the herbage seeking a suitable stem here, or a leaf there, upon which to place an egg or two. Later on both sexes will have retired to their sleeping quarters, the males on the flower stems of grass or other plants, and the females frequently in a more lowly position. This habit, which is common to all kinds of blue butterflies, as well as the small coppers and some others is very convenient to the entomologist, as it enables him to examine large numbers without much trouble to himself or injury to the insect.

The exceedingly nimble little yellowish butterfly that we have seen so frequently, but which has eluded close inspection, so far, is the silver-spotted skipper. There is one on that flower-head of the low-growing thistle. As is usual when these butterflies settle the wings are closed, and only the undersides of them can 


\section{BRITISH BUTTERFLIES}

be seen, but these show the silvery markings which are the characters by which this butterfly can very easily be distinguished from any other of the eight kinds of skippers found in this country. 


\section{DAY-FLYING MOTHS}





\section{$\mathrm{X}$}

\section{DAY-FLYING MOTHS}

"But she, God love her! feared to brush The dust from off its wings."

\section{-WORDSWORTH.}

MENTION will first be made of a few kinds that are distinctly sun lovers-Burnets and Foresters, Clearwings, day flying Hawk Moths, etc.

The most generally distributed kind of Burnet is that known as the Six-spotted, and this is perhaps most abundant near the coast, where it may be found in large colonies in favourable hollows on cliffs, downs, and sandhills. In its inland homes on sheltered hillsides, meadows, and railway banks, it is not much less common. The moth, which has the forewings glossy, deep bluish-green and the six spots thereon of the same crimson colour as the hindwings, flies about somewhat in the manner of a bee. It is fond of settling on thistles and other composite flowers, and sometimes quite a number may be seen resting together. When the sun is obscured they become inactive and may then be easily 


\section{BRITISH BUTTERFLIES}

captured, but directly the sun appears again they are quickly on the alert. The caterpillar, which is a flabby and sluggish sort of creature, is greenish in colour and is marked with black and yellow; it feeds upon clover and bird's-foot trefoil. The cocoon is most conspicuous, fixed as it usually is about half-way up a grass stem. It is a shuttle-shaped affair, more or less white as regards colour, and of a glistening, papery texture. If one of these cocoons is opened a shining black chrysalis will be found within, or it may happen that the maker of the domicile will then be exposed still in its caterpillar state.

The female moth lays eggs of a yellowish colour in batches, and in large numbers. The caterpillars hibernate and many doubtless perish or fall victims to some foe. Those that survive until the spring are then subject to the attacks of parasitical flies, and the numbers destroyed in this way is sometimes, in hot seasons especially, very large. Even when the chrysalis state is attained without mishap, all danger is not over, as the contents of these cocoons appear to be to the taste of sundry birds, and even mice seem to have cultivated a liking for them. It is perhaps surprising that they escape complete annihilation. They come near such a catastrophe in some years.

Two nearly allied, but rather local, kinds of Burnet Moth have only five crimson spots on the forewings. 


\section{DAY-FLYING MOTHS}

These are the Broad-bordered and the Narrow-bordered. The former is found in marshes and meadows, and the latter in and around woods.

Three other species are very local. One is the New Forest Burnet and is like a small specimen of the Broadborder. In England it is confined to certain limited areas, of a somewhat marshy character, in the district from which it receives its name. Another species is the Transparent Burnet, which is found in localities near the coast in some parts of Scotland, Ireland, and Wales. It was first noticed in Ireland, and was therefore called the Irish Burnet. The third of these very local kinds is the Scotch Burnet, which seems to be peculiar to the Aberdeenshire mountains.

Of the Foresters only three species are known to occur in Britain. The English names of these are the Green Forester, the Scarce Forester, and the Small or Cistus Forester. All have golden or coppery-green bodies and forewings, and greyish hindwings. The first mentioned is the most widely distributed and is usually found in moist meadows. It is, however, curiously restricted to some particular portion of the field in which it occurs. The pink flowers of the Ragged Robin seem to be a favourite resting-place, and when it is thus reposing it is less easily seen than one would imagine. Under the influence of sunshine it is very active on the wing, but rarely flies far from its breeding 


\section{BRITISH BUTTERFLIES}

ground, which, as has been adverted to, is of very limited area. The caterpillar is dull yellowish with pink markings, and it feeds on the leaves of sorrel.

The Clearwings, which, from their superficial resemblance to some species of Hawk Moths with transparent wings, were up to quite recent times associated in classification with the Sphinges, are for the most part only obtained in the winged state on bright sunny days. Fourteen species are found in Britain, and the two largest of these bear a strong likeness to hornets and wasps. These Hornet Clearwings, as they are called, are rather sedentary in habit, and are most often seen sitting on the leaves and boles of poplars and osiers, in the stems, trunks and roots of which their caterpillars were nourished. The other ten members of the group are individually less in size, but they also resemble species of Hymenoptera, to which order hornets, wasps and bees belong. They delight in resting on leaves to bask in the sunshine, and at such times they seem to offer the collector an easy chance of annexing them; but when the sun shines the listlessness is in seeming only and not in fact. The Clearwing Moth is very much awake, and exceedingly nimble withal. Perhaps the best known, certainly the most generally distributed, species is the Currant Clearwing. In spite of its fairylike appearance it is capable of doing considerable damage when it once succeeds in establishing itself in a 


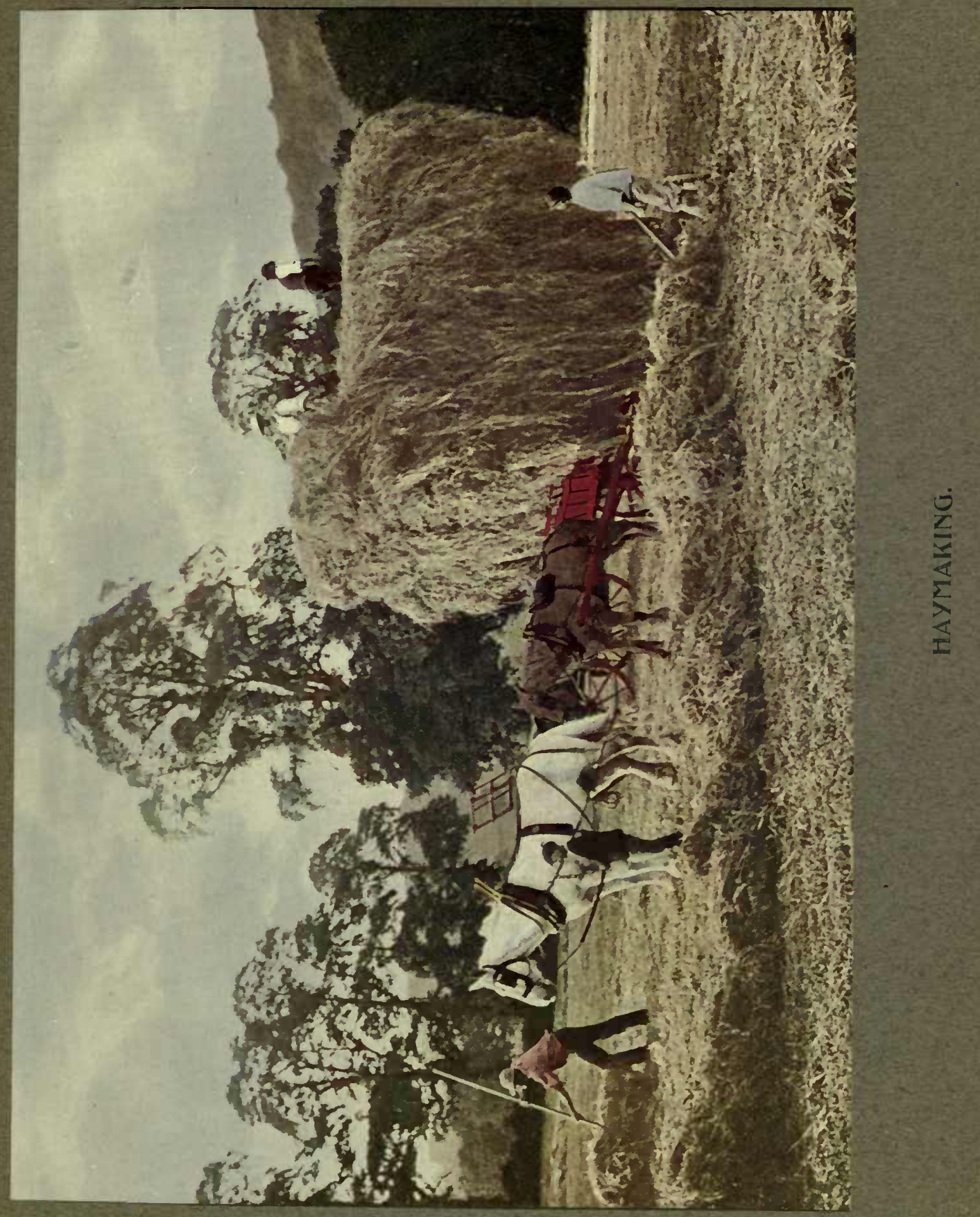




\section{DAY-FLYING MOTHS}

garden where currants are grown. It has a particular fancy for the black currant bush.

The female moth lays a number of eggs and each one is carefully deposited near a bud, so that the caterpillar when it hatches is in a position to bore into the stem right away. When it has reached the centre of the stem it feeds on the pith both above and below the point of entry. In due time it attains full growth, and it then gnaws through the woody walls of the stem, but stops short at the thin outer skin, which is left intact so as to protect the chamber whilst the insect is in the chrysalis state. The chrysalis, about the time when the moth is ready to emerge therefrom, is worked towards the outlet by means of the hooks with which the body is provided. Subsequently pressure is brought to bear on the outer skin of the stem, this gives way and the front half of the chrysalis is then protruded from the opening. After a while the moth escapes from the chrysalis shell, and the latter remains with the hind portions still in the hole.

The Broad and the Narrow Bee Hawk Moths are true Sphinges, and although the wings are clear these moths are not directly related in any way to the Clearwings alluded to above. The Broadbordered is the commoner of the two, and in late May and early June when the rhododendrons are in full bloom it is an interesting sight, on a sunny morn- 


\section{BRITISH BUTTERFLIES}

ing, to watch these pretty insects engaged upon the open flowers. Humble Bees, to which the moth is very similar in many respects, always settle on the blossom they investigate with felonious intent. The Hawk Moth on the other hand remains in front of the flower, as though suspended by a thread, and probes the nectary with its long sucking tube without alighting. How suddenly it darts to the right, or to the left, just as the would-be captor is making ready to envelope it in the net. When seen on the wing these moths always have the wings, except the edges, quite transparent. When freshly emerged from the chrysalis the wings have a covering of dusky scales, but these are so loosely attached that the first flight of the insect removes them.

A rather near relative of the Bee Hawks is the Humming Bird Hawk Moth, which although not observed in Britain every year is sometimes quite common, and may be seen in gardens even in large towns, and occasionally in London itself. The wings of this moth are fully scaled; the fore pair are brownish in colour, crossed by two black lines, and the hind pair are orange marked with brown. Like the Bee Hawks, it also takes nourishment in a hurry and remains on the wing whilst obtaining it. As an adept in eluding the toils of the entomologist's net it is even more accomplished than either of those moths. Although it may 


\section{DAY-FLYING MOTHS}

perhaps have a preference for the sweets to be found in tubular flowers, such as honeysuckle, jasmine, or valerian, it may often be seen probing and testing the saccharine productions of various kinds of blossom.

It is essentially a sun-loving and day-flying moth, but it apparently takes a midday nap, as it is chiefly seen in the forenoon and again after about two o'clock. These periods of rest and activity may synchronise with similar stages in plant life.

Among the divisions of Lepidoptera known as Arctiidæ, Noctuidæ, and Geometridæ there are several species with the day-flying habit strongly developed, but space will only suffice for brief mention of a few of the more generally distributed of these.

Although many of the Arctiidæ, or Tiger Moths, are more or less active in the daytime, they do not get on the wing in quite the same voluntary manner as does the Cinnabar Moth. This insect, with its crimson splashed blue-grey forewings and crimson hindwings, imparts life and colour to the rough fields and waste places in which it disports itself, on sunny days, in the early summer time. The caterpillars, which are orange with black rings, are often exceedingly abundant on ragwort, but the moths are rarely very numerous. It is one of the moths designated common that the tyro is enraptured with on first making its acquaintance. He shows it to the expert in great glee, 


\section{BRITISH BUTTERFLIES}

but immediately feels sad when he learns that it has no claim to rarity.

In sanfoin and lucerne fields, and in rough fields with plenty of bindweed among the herbage, especially in chalky districts, will be found a pretty, active, little Noctuid Moth. It is black in colour with a white blotch on each wing, and is known to the collector as the Four-spotted. It flies briskly in the sunshine, but it is also on the wing in the evening.

Then there are the Beautiful Yellow Underwing, not uncommon on most heather-clad commons and moorlands; and the Small Yellow Underwing, often to be seen in some numbers in meadows, etc., in May and early June. Both these insects are lovers of the sun, and are only active in the daytime under its influence. As may be gathered from the English names, each species has yellow hindwings, but in the first named the forewings are purplish or reddish-brown marbled with white and otherwise marked with yellow ; in the other species the forewings are brownish marked through the mid area with blackish.

In meadows, and flying with butterflies of the Skipper persuasion on rough grassy hillsides, will be seen in early summer the Mother Shipton and the Burnet Companion. The former of these species has the forewings brownish mixed with grey, and upon them a design in ochreous or whitish which may be 


\section{DAY-FLYING MOTHS}

likened to a grotesque profile of a human face, and distinctly of the conventional witch-like pattern. The wings of the latter species are as regards the upper pair greyish brown varied with a purple sheen, and crossed by darker brown bars; the lower pair are orange yellow, marked with brown.

The species now to refer to in the present connexion are one or two members of the Geometridæ, a family of moths that afford the collector plenty of day sport throughout the season. The majority of these species are induced to break cover very readily, by means of the beating stick, but a few are day-fliers because they feel that way inclined. The first on the list is a pretty little fellow with black marked yellow wings; this is the Speckled Yellow Moth of our woodlands. Then in the pine woods there are the males of the Bordered White, and on moors and heathery ground the same sex of the Common Heath. The females of these two species last mentioned do not fly freely until early evening, and then their chief business is egg-laying. 



\section{THE ENTOMOLOGIST'S METHODS}





\section{XI \\ THE ENTOMOLOGIST'S METHODS \\ "The virtuoso thus, at noon, Broiling beneath a July sun, The gilded butterfly pursues \\ O'er hedge and ditch, through gaps and mews; \\ And, after many a vain essay \\ To captivate the tempting prey, \\ Gives him at length the lucky pat, \\ And has him safe beneath the hat; \\ Then lifts it gently from the ground; \\ But, ah! 'tis lost as soon as found. \\ Culprit his liberty regains, \\ Flits out of sight, and mocks his pains."}

- COWPER.

To capture a butterfly with a net, of even Brobdingnagian proportions, is not always the soft thing it seems to any one who has not attempted the feat. The insect has settled on a tall thistle blossom; you approach stealthily until, as you judge, you are within striking distance of the object. With a grand sweep the net travels rapidly in the direction of the quarry, but although it has decapitated the thistle it does not enclose the butterfly. It was just that elegant sweep 


\section{BRITISH BUTTERFLIES}

that lost the fly; next time get the net rather higher than the thistle head and then strike downwards and obliquely.

Two collectors are busy among the butterflies in a clover field. One has taken up a position and quietly nets the right kinds as they come within range. The other is rushing about hither and thither; he does not catch much, but he is taking plenty of exercise, and incidentally doing some damage to the farmer's crop. Again, in disturbing moths from their resting-places in hedgerows, bushes, etc., one collector will slash away right vigorously, but he seems anxious all the time to push on as fast as he can. Insects leave their retreat in response to his summons, but he does not see them because he has passed the spot when they emerge. Most of those moths will return to cover and be secured by the collector who, working methodically, has lagged behind his companion. He gently taps the twigs here and there, pokes his stick well into the hedge and stirs up the vegetation growing below, but he faces his work all the while and very little escapes his wary eye. There is, too, this further difference in the tactics of the two; the collector in a hurry boxes or kills outright everything he succeeds in bagging, whereas the slower worker carefully examines all his catches and at once liberates anything he does not require. 


\section{THE ENTOMOLOGIST'S METHODS}

Although it is always well for the collector to have the implement with him when on an entomological foray, the net is not the all-important article it may be considered. There are collections of butterflies which for the most part comprise only bred specimens. In some cases the net may have been used to capture female butterflies from which to obtain a stock of eggs, but the majority of the specimens contained in such collections have been reared from eggs, or from caterpillars obtained by searching or beating among the food plants of the various species. It would be possible, too, to acquire a very respectable collection of moths without using the net at all.

Searching low-growing herbage by day, or by the aid of a lantern at night, is a bit trying at first, no doubt, and some collectors may think the business too wearisome. Success in this kind of work is probably a matter of temperament. A good stock of patience and a sharp eye are the essential requirements, and being armed with these the egg or caterpillar hunter will find that practice overcomes seeming difficulty and leads to proficiency.

To obtain leaf-eating caterpillars from trees or bushes, the collector with one hand holds an open umbrella under the branches, whilst with a stick in the other hestrikes from above in the direction of the receptacle held below. Sudden sharp thumps on the 


\section{BRITISH BUTTERFLIES}

thicker part of a branch are usually more effective than any amount of indiscriminate thrashing of the foliage and smaller twigs. Some collectors, however, prefer to search the leaves and twigs for the caterpillars and rarely bring the beating stick into action.

Two friends, one an advocate of forcible ejectment, and the other an expert in the more gentle art, decided to test the two methods when on an expedition for caterpillars of the Large Emerald, which feed on birch, hazel and alder. At the close of the trial the searcher had eight caterpillars and the beater only two. Seven moths were subsequently reared from the eight caterpillars, but neither of those that fell to the beating stick reached the chrysalis stage.

It is the habit of many kinds of moths to sit during the day on tree-trunks, rocks, palings and other sorts of fencing, etc., and the collector often secures a goodly bag by simply walking about a wood, or by the side of a long stretch of paling. Some moths are rather conspicuous objects when resting in this way, but others seem to so closely match whatever they are upon that their detection is at first somewhat difficult. Many collectors become such adepts at the sport that they can not only see a moth on a tree several yards away from them, but very often they can tell whether or not it happens to be of the kind they want. Such efficiency is, however, only acquired by considerable experience. 


\section{THE ENTOMOLOGIST'S METHODS}

The bulk of the moths found in this way may be boxed without much trouble, but some kinds are rather skittish and fly from their perch on the approach of the collector. In such cases the net comes in handy.

The collector will need to familiarize himself with those plants whose blossoms are attractive to insects. Of these sallow, which blooms in early spring, and the autumnal flowering ivy are especially to be located, so that each may be worked in its season. Isolated bushes of the former, when growing in or near woods, are more remunerative than large and dense masses. Swarms of bees and flies visit the yellow catkins, the so-called "palm," during the day, but at night moths gather together from all quarters, and carouse on the nectar drawn from the blossoms. The method of collecting the moths is similar to that employed in beating for caterpillars just referred to. The tapping, however, should be even more tenderly done. The insects fall readily and will remain perfectly still for a time. When they arouse themselves they crawl quietly towards the edge of the umbrella or whatnot. There is always plenty of time to examine the inebriates by the aid of a lantern, and to select such of them as may be required. Ivy is worked much in the same way, but sometimes, as for instance when the plant grows on the sides of a wall or house, the lantern will have to be turned on and the moths boxed from the flowers direct. 


\section{BRITISH BUTTERFLIES}

In most woods that are more or less open to the public it will be noticed that the trees on each side of the rides, and on the edges of the wood, have blackish vertical patches on their trunks. These marks do not indicate that such trees are to fall under the woodman's axe. They are the signs manual of the collecting craft, and result from frequent applications of the saccharine composition which the collector uses to attract those moths that have a partiality for sweets. Although the basis of the mixture is either brown sugar or treacle, or both, reduced to a workable consistency by boiling in beer, there are various recipes for the preparation of the bait. Very often the compound is finished off by the addition of a modicum of rum, and some collectors put in a drop or two of the essence of jargonelle pear or ribston pippin. Not infrequently it happens that the moths are not to be tempted by anything in the way of sweets that the collector may prepare. What the meteorological or other conditions should be exactly is not clearly understood, but certain it is that on some evenings, ordinary treacle spread on the tree trunks will allure moths by hundreds, while on another night equably favourable so far as one can judge, not a single moth will put in an appearance, even although the most cunningly concocted mixture has been put on. When, however, the moths do attend the feast provided for them, the 


\section{THE ENTOMOLOGIST'S METHODS}

collector's heart is glad, and he enjoys an hour or two of considerable excitement moving from tree to tree, selecting a specimen here and another there. As each patch of sugar is approached and the light of the lantern allowed to fall upon it, the collector is on the tip-toe of expectancy, for what grand prize may the flash reveal! A Small Mottled Willow, perchance, or perhaps a fine example of the Blue Underwing or Clifden Nonpareil. Even among the things of less rarity there are many which give the collector pleasure to see at the banquet. When the attendance of insect guests is large, what a scrimmage there is between those already feeding and the new arrivals anxious to obtain a share of the entertainment. Some of the larger kinds, such as the Dark Arches and the Yellow Underwings, are quarrelsome fellows, and delight in rowdyism, much to the discomfort of the quieter sorts. At the foot of trees that are frequently sugared it is not uncommon to find a well-nourished toad seated and patiently awaiting whatever may fall from the festive board above him. Centipedes also get to know of the moth gatherings, and find that a supper is easily to be obtained on such occasions. 



\section{HUMOURS OF INSECT LIFE IN OCTOBER}





\section{XII}

\section{HUMOURS OF INSECT LIFE IN $O C T O B E R$}

"Shake not his hour-glass, when his hasty sand Is ebbing to the last;

A little longer, yet a little longer-" -DRYDEN.

IN the early morning a tattered blue butterfly comes from a hiding-place in the dewy grass, flits aimlessly across the field, and drops into the shelter of the hedgerow. Unseen he had rested, clinging to an upright stem, till disturbed as I walked through the meadow. Inquisitive, I stoop to examine the stalk from which he rose. It still sways lightly from the shock caused by the insect's hurried departure. All its dewdrops have been sprinkled on the soil, and near its root a brown beetle clings asleep. Among the grasses I find many other butterflies, one here, another there, sometimes two on a single stem. So closely folded are the insects' wings, so fittingly decorated in neutral hues of grey with yellow spots, that each butterfly seems to be 


\section{BRITISH BUTTERFLIES}

part of the stalk on which it reposes. Saved from harm by the loving care with which Nature has made every minute scale on the fragile fans match some surrounding tint in the undergrowth, the motionless insects await patiently the disappearance of the dew. The warmth of the previous day called some of them to life, but others resemble their weather-worn companion that flew before me a moment ago : their sum-. mer is past; they will probably die when day closes over the fields.

Towards the south, a long bank of rose-tinged cloud, overhung with a thin curtain of pale primrose, hides the risen sun. A partridge calls from the silence of a distant stubble; the gossiping rooks caw harshly as they sail overhead on their way from the elms on the slope of the hill to the ploughlands near the river. Among the oaks near the outskirts of the wood the ringdoves are already astir, seeking among the branches a meal of ripe acorns; and the eager cooing of these most amorous of forest lovers is heard in every part of the valley.

Close by, the webs of the geometrical spiders glimmer among the bushes; and long silken strands, marking the wanderings of these weavers of the night, are stretched from twig to twig across my path. Now that the sun's power is waning, and insect life is rarer day by day, the spider becomes unusually diligent. 


\section{HUMOURS OF INSECT LIFE}

She needs to be well fed before the wasting sleep of winter and so must not fail to secure a plentiful supply of flies. Though at other times careful of her store of silk, she does not hesitate now to weave a new net whenever she may require it, if but the day hold out a promise of fair weather. To prepare for her long sleep seems to be the spider's chief purpose when autumn comes. The law that determines her existence is the survival of the fittest: so, if through accident or extravagance her silken supply is exhausted, she quickly visits the web of a near neighbour, and contends with the owner for possession. Such a battle frequently results in the death of one of the combatants, and then the victor leisurely proceeds to feast on the body of the slain. Should the aggressor be also the conqueror, she makes a careful survey of her new abode, and soon settles down to the enjoyment of her ill-gotten gains. In time her store of silk is so renewed that when she lays her eggs she is able to enclose them in a watertight cocoon. This task completed, she at last retires to some sheltered cranny in the hedge, and there constructs a silken chamber in which, secure from rain and cold, she sleeps the winter away.

As the sun rises above the pink clouds at the horizon, the yellow curtain in mid-sky fades into an almost transparent veil, and gradually vanishes. The mist 


\section{BRITISH BUTTERFLIES}

rises in steam from the grass, and collects in dense cloud-masses which, following one another, roll slowly across the meadow, and spread out over the rank herbage by the hedgerow, like smoke-puffs from the sportsman's gun on a November afternoon. Half an hour since, I noticed that all the webs in the furze brakes around had evidently been completed before the dawn; for no spider continued at work among. the strands. The reason for this early toil is apparent. Had the spiders delayed their tasks till the moisture rose from the grass in the growing heat, their threads would have been softened and rendered useless even as they were spun. But since the webs have been hardened by the cool night air, the passing mist only decks them with a thousand pearls, that trickle along the threads and fall to the grass, or are in turn absorbed by the heat.

When, later, I come again into the fields, the mist has gone, but in the shadows beneath the leaves the dew still lingers. The pearls of dew, that were flushed by the rose-tinge of the eastern sky, have, in the clearer light, become diamonds, that glow and sparkle with a dazzling radiance almost unbearable to the eye. A few late spiders, less learned, perhaps, in weather-lore than their companions which spun during the night, but finding that the mist has disappeared, are busy placing their snares among the brambles for the unwary 


\section{HUMOURS OF INSECT LIFE}

flies. Passing some large trees in the hedgerow, I notice on the trunk a number of Vanessa butterflies. Just as with the little Blues, the colours on the underside of the larger insects are similar to those of their surroundings. A Painted-Lady, resting on a broken branch, seems like a patch of lichen; while, near by, a Peacock, with closed wings, looks like a charred stick, and is scarcely distinct from the shadow in the crevice on the edge of which it rests.

Presently, enticed by the gentle warmth, the butterflies leave their hiding-places, for the flowers are full of honey and await their coming. They flit idly about the blossoms, but their favourite resort is a clump of valerian, on the crimson crowns of which three or four of them bask, with spread wings, and probe between the clustered petals. Not only the big Vanessas love the sweet juices of the valerian. A little Copper flits down from the oaks and drives away a Peacock from the flowers ; then, while her studded fans reflect on their burnished scales the brightness of the morning, she enjoys a sumptuous feast. Soon the Copper butterfly is pursued by an eager mate. Coyly, with trembling wings, she resists his advances, but the ardent admirer pursues her to the edge of the valerian; then they flit into the air, and gambol round each other till, rising higher and yet higher, they disappear over the tops of the oaks. 


\section{BRITISH BUTTERFLIES}

The chirrup, chirrup, of the grasshoppers in the light is to-day almost as incessant as when the hot sun scorched the dry fields in July. In one spot, where a long, shaft-like shadow is thrown from a ruined wall, the insects are strangely silent, and seem to be endeavouring to escape from the darkness. Repeatedly they leap far above the shadow, as though wishful to feel for one brief moment the pleasurable glow of autumn sunshine beyond the gloom of their little world.

A spider, when viewed closely beneath a powerful glass, wears a sinister and forbidding aspect, befitting the cruel life she leads. But the 'grasshopper, a harmless vegetarian, possesses an almost owlish countenance suggestive of sober wisdom and grave responsibilities, as if she had heard every secret of Nature whispered by the passing wind in the grass. As I watch intently a female grasshopper nibbling quietly and carefully a single blade of grass I cannot fail to smile. Her antennæ project before her face almost like quill pens stuck forward in the ears of some village schoolmistress. Her big, bulging eyes; her long-drawn visage fringed with the palpi, or lips, that continually move as she feeds; and the blunt, beak-like mouth, all combine to render her appearance curious and antiquated. I can hardly imagine a suitor for the affections of this queer little dame. Nevertheless, he presently appears, peeping from behind a twig, and approaches cautiouslyro6 


\section{HUMOURS OF INSECT LIFE}

in trepidation, it would seem. His eyes are set further in front than hers, and his aspect is not so particularly venerable. He gently lifts his legs, and utters a faint chirrup, calculated, perhaps, to assure her of his admiration ; but she makes no response. Now he crawls still nearer, takes the grass-blade which she is daintily nibbling in his front claws, and holds it obligingly for her in a better position. But she gnaws away, and he, preoccupied with her charms, fails to notice that the grass-blade is gradually disappearing close to his claws, till with a sharp nip she reminds him that her business is eating, and causes him to relinquish hastily his hold. His next attitude is absurdly funny. While he grasps the surrounding stalks with his four hind-feet, his frontclaws seem to have nothing to do. He clasps them in an unintentional attitude of supplication so comical that I laugh aloud ; and alas ! the grasshopper's wooing is indefinitely postponed. A grasshopper, while nibbling a green blade, holds it in such a position that her jaws cut through it edgewise, and in a curve of which the lower extremity is nearer to her body than the point at which she commences to gnaw.

All this I have seen as I crouched in the grass. As I walk by the fence I notice a dragon-fly, belonging to the largest of our British species, resting on a leaf. The body is rich olive-brown in colour, with a delicate bloom, like that of the sloes in the hedgerow, at the lower end 


\section{BRITISH BUTTERFLIES}

of each overlapping spiracle, and is crossed with bands of white. The dark eyes glisten like polished greenstone; and in the transparent gauze of the rainbowwings lurks every colour of foliage and sky. A robin flits past, with a quick jerk of his wings, and alights on the grass. Disturbed, the dragon-fly flashes off into the sunlight, and, as if pretending to ignore the false alarm, commences in a business-like fashion to hawk for flies near the ditch. Now is witnessed a marvellous display of its powers of flight. Like a miniature airship balanced perfectly between swiftly revolving propellers, the dragon-fly goes straight as an arrow, skimming the heads of the valerian, and nearly touching the top of the furze under the oaks. Suddenly it halts, and its wings rattle and scintillate in the amber light of the morning. Then, reversing the action of its fans, the insect moves backward for an instant, and hangs above the crown of a blue field-scabious in the ditch. Finding that the small flies, which chiefly form its food, have gone from the neighbourhood of the flower, the dragon-fly, with a sharp alteration in the movements of the wings, turns head and thorax towards the sky, and, like a clubbed arrow shot from an invisible bow, ascends to the level of the midmost branches of the oaks. Thence, with another equally rapid change of flight, it passes along the outer leaves. Again it stops, and again the sunshine touches the trembling wings. I08 


\section{HUMOURS OF INSECT LIFE}

Almost immediately afterwards it vanishes-it has dropped so quickly that my eye is baffled in seeking to ascertain its whereabouts-till yet once more the shining film of lace-like wings may be observed among the brambles close at hand. Creeping stealthily towards the tangle, I notice that the head of the dragonfly is turned restlessly, now on one side and again on another, as the insect keeps a sharp watch for its prey. The light green lips are opened and closed, as this. marauder of the woods devours some savoury morsel just secured, but I am unable to discover the identity of the stricken insect. Having finished its meal, the dragon-fly flashes off in pursuit of one of its species which has come to trespass on its hunting preserve, and drives the intruder away. Returning from the chase, the ravenous creature spies a drone-fly quitting a broad leaf of plantain, and drops instantly, hoping for a richer repast, but rises again, reluctant to attack an opponent of such formidable appearance. It may be that the drone-fly owes its escape to the accuracy with which Nature has counterfeited the colour and shape of the hive-bee in this less intelligent wildling of the fields, which, however-as the dragon-fly is probably unaware-cannot sting. Gliding, pausing, rising, falling, the dragon-fly inspects the upper surface of every leaf and flower in its neighbourhood, and consequently a rather heavy rate of mortality takes place among the 


\section{BRITISH BUTTERFLIES}

gnats. But the gnats are not the only sufferers. Down from an oak bough flits a long-tailed titmouse, evidently in pursuit of a fly; but it fails to catch its quarry, and returns to the fence-rail beneath the branch. Almost directly afterwards, the dragon-fly skims across between the trees, swoops down, and appears to pick off something from a thistle close to the spot where the tit turned back baffled in its chase. Whether the bird has attracted the attention of the dragon-fly to the thistle, or whether the sight of the insect is far more acute than that of the tit, I cannot tell ; I recognize, however, that in the dragon-fly the power of wing is much more wonderful than in the titmouse, making the insect a perfect acrobat of the air, compared with which the bird is like a member of some untrained troupe. Having struck its prey, the dragon-fly carries it to a neighbouring plant, their feeding leisurely on what I afterwards find, from a fragment of chitine left on the spray, to have been a bright green insect, slightly similar, but for its colour, to the familiar house-fly.

While hawking, generally along the margins of the woods, the dragon-fly, if passing to and fro in a favourite line of flight, inclines its head towards the ground, and tilts its abdomen slightly above the thorax. Its large and almost spherical eyes cover a considerable field of vision, if not the entire surroundings. From the shape and size of the thorax, it is at once apparent 


\section{HUMOURS OF INSECT LIFE}

to me that the muscles controlling the action of the wings are numerous and extremely powerful. This conclusion is fully warranted by an examination of the wings themselves, which in every part are tough and firm, but where joining the thorax are especially strengthened and stiffened by thick, tapering nervures forming the framework of a shining, elastic gauze stretched tightly between the dark brown veins.

From the moment of its transformation into the larval condition to the time of its death, the dragonfly is a pitiless destroyer of weaker insects. During the larval and pupal stages of development it dwells in a pond or in a stream. There the creature's appetite is ravenous, and sometimes it becomes a cannibal, devouring even its own kin. Yet, in its perfect state, this swift-winged tyrant arouses admiration by the grace of every movement. The very audacity with which it approaches and dares to hover before me, as if inquisitive concerning my trespass among its haunts, causes me to regard it as an object of more than ordinary interest.

But there is a certain family of insects, similarly cruel, for which I can cherish no kind of regard-the robberflies. The members of this tribe most commonly seen in the fields are comparatively sluggish in their habits, and are of a dull grey colour, or banded with black and yellow. On a wooden rail, not far from the dragon- 


\section{BRITISH BUTTERFLIES}

fly's preserve, I find one of the grey robbers engaged in sucking the juices from the body of a small, wasplike insect. Though effectual in screening the dronefly from harm, the mimicry of Nature has evidently been insufficient to preserve the robber's victim. As is usually the case, the robber-fly may have struck its prey while both were on the wing, and when the protective colouring of the wasp-fly-which fulfils its purpose chiefly as the creature rests on a yellow flowerwas of little avail.

The diligent wasps are still abroad in the fields, and are engaged, like the bees, in providing for their winter wants. As I pass a fallen tree-trunk, an angry buzz warns me that I have started one of these insects while at some important task. The wasp circles several times about my head; then, reassured, flies to the prostrate tree, seeks a place where the bark has been stripped off by the wind, and begins to collect woodpulp, with which, undoubtedly, to repair her nest. A leaf-cutter bee can be heard as she shears through the harder portions of the leaves; and, similarly, the sound produced by the jaws of the wasp, while she patiently tears away minute fragments of pulp, is at once noticeable as I stoop to watch this skilled mechanic of the hedgerow. The wood is hard; her labour difficult; and a considerable time elapses before she has gathered sufficient for one journey to her nest. 


\section{HUMOURS OF INSECT LIFE}

Having apparently masticated the pulp and reduced it to a condition fit for her purpose, she flies to the hedgerow bank, where, behind a frond of brake fern, she disappears within the shadowed entrance of her underground abode.

The afternoon declines as I return homeward from the fields. Among the brake-fern on the outskirts of the woodlands the midges are numerous and troublesome, for the dragon-flies are at rest among the leaves. When the sun sinks in the west, dusky moths commence to flutter around the pale evening-primrose in the rough pastures on my way over the slope of the hill, while a noisy beetle booms up from the grassy lane leading to the village, and passes into the gloom, with a loud murmur that gradually becomes fainter and fainter, and at last dies away across the swollen river. 



\section{THE MAKERS OF GOSSAMER}





\section{XIII}

\section{THE MAKERS OF GOSSAMER}

"Autumn grows old: he, like some simple one, In Summer's castaways is strangely clad;

Such withered things the winds in frolic mad Shake from his feeble hand and forehead wan."

-William H. Davies.

As a season for the outdoor study of Nature, the month of November hardly strikes one as altogether congenial. To the enthusiastic ornithologist it may furnish an opportunity for the observation of many of our rarer birds ; the energetic lepidopterist, too, may brave its dreariness in search of pupæ: but to the man in the street-and, still more so, the man indoors-Nature appears to have put up her shutters and bidden her manifold creations rest-or perish.

Put on a pair of thick boots and come with me, my friend, and I will prove to you that Nature has not quite fallen asleep and that some, at least, of her children are as wide-awake as ever. No, do not bring your gunthe woods and fields are dreary enough already without 


\section{BRITISH BUTTERFLIES}

any assistance on your part. We will walk through the park, although our ramble will be restricted by yonder serried row of iron railings which the owner has erected for the preservation of his hundreds of acres.

Why, what is the matter now? Another cobweb across your face? I am glad, for it foretells much sport in store for us. Where do you think these flying threads come from? You have read all about it? I am glad of that: perhaps you will tell me. No, my dear fellow, you are quite wrong. The book was right as far as it went, but it did not go far enough. There is no doubt that the orb-spinning spiders employ flying threads as a means of forming foundation lines in the construction of their snares. But these interesting creatures have, by now, in the majority of cases, laid their eggs, snugly enveloped in a thick silken covering and, having completed this all-important task, have come to the conclusion that life has no further attraction for them. A comparatively small number of half-grown individuals lie in hiding awaiting the return of spring, but they would hardly dare to venture abroad on such a cheerless day as this.

Look carefully at the tiny black spider perched upon the pinnacle of this railing. It is not a youngster as you might suppose, but an adult spider in the full glory of his manhood. How do I know? Simply enough. Do you see those prominent organs in front of his head, 


\section{THE MAKERS OF GOSSAMER}

somewhat resembling arms with very large, complicated hands? They are known as palpi; and the presence of the complex organs at the extremity of each of them is a sure criterion that the creature has arrived at the adult stage. Had it been a female, your microscope would have been necessary in order to satisfactorily decide as to its condition of maturity.

Watch the antics of the little creature carefully, and you will be amused. See, it is dissatisfied with the pinnacle which at present supports it, and is taking advantage of a bridge of delicate silk, obligingly formed by one of its predecessors, to explore the next railing, which, to our eyes, appears exactly like the other. Still it is not satisfied. First it tries one point, then another, striking curious attitudes, and, at intervals, pirouetting wildly upon its dainty feet, its whole demeanour obviously suggestive of extreme excitement. It is only natural, for the little creature is making its final preparations for a voyage of discovery and adventure to a land of which it knows nothing and from which there is little chance of its ever returning.

At last it seems satisfied with the particular railing upon which it stands, and is raising its body to the utmost extent by straightening its legs in an almost ludicrous manner. Do you notice that from the spinners at the extremity of its abdomen there has issued a line of web of such tenuity that it is only visible when 


\section{BRITISH BUTTERFLIES}

the light strikes it in certain directions? Incredible as it may seem, this thread is not simple, but consists, in reality, of quite a large number of filaments, being, in fact, somewhat of the nature of a ribbon, and intended to offer as considerable a resistance to the breeze as is possible. Although you cannot actually confirm it in the present instance, you may take my word for it that this ribbon is being paid out with wonderful rapidity.

It was formerly believed, chiefly by reason of the fact that these lines are often cast on days when there is no perceptible motion in the air, that the spider could project them where and when it chose: but experiments made with air rendered perfectly stationary by scientific means have demonstrated the fallacy of this supposition, and have shown that an air current is absolutely necessary. It is, however, manifest that a breeze quite inappreciable to the human senses would be sufficient to carry a ribbon whose delicacy is such that spun silk, by comparison, is course and heavy.

The thread is formed from a viscous liquid, secreted by special glands in the body of the spider, which liquid, when brought into contact with the air in the finely divided state exhibited in these filaments, hardens immediately, and forms one of the strongest cables, in proportion to its size, that Nature or man can produce. Notice how tenaciously the little creature 


\section{THE MAKERS OF GOSSAMER}

clutches the railing. It is necessary, for he has probably, by this time, several yards of ribbon to contend with, and the pulling force must be considerable. There he goes! He has estimated to a nicety the pull of the thread and away he sails over the meadow. His direction is controlled by the prevailing breeze, and by the rising air-currents; but he is not altogether at the mercy of these fickle agencies, for he is able, by lengthening or drawing in his thread, to rise or to descend. But whether he shall travel north, south, east or west he has no choice whatever.

We may premise that his voyage will end safely, for in all probability he will be brought to a standstill by yonder row of stately elms. But it is not always so. If you are fortunate enough to be on the cliffs in the late autumn, with a very gentle land-breeze blowing, you will be able to observe large numbers of minute spiders sailing out to sea. We are often told that man has been forestalled in many of his mechanical contrivances by spiders; but few may be aware that, long before man essayed in one curious way or another to cross the channel, these tiny creatures had perished in millions, unconsciously attempting the same feat.

You thought spiders were more intelligent? I remember, a few years ago, in the early autumn, noticing an orb-spinning spider perched upon a knapweed head on the very brink of the cliff at Dover. Closer 


\section{BRITISH BUTTERFLIES}

inspection revealed the fact that it was paying out a thread as the foundation line for a snare, expecting, as is usually the case, that it would ultimately become entangled in some neighbouring object. Unfortunately, from the direction of the wind, the line was drifting directly towards the French coast, and the nearest available object was at a distance considerably more than twenty miles. After a prodigious amount of thread had been thus expended, the spider seemed to come to the conclusion that it must have caught somewhere, and, acting upon this supposition, walked boldly out to sea. I watched for some considerable time but never saw her again.

But let us return to our railings. Look at this little creature just preparing to vacate its perch. I will postpone its journey by breaking its thread, because I wish you to examine it closely. Take this lens: its magnifying capability is only about three diameters, but it will help you considerably in making out the structural peculiarities of your victim. Take particular notice of the shape of its head. Do you see that instead of being bluffly rounded as in the majority of spiders it is drawn out into a kind of conical elongation with a tuft of hairs at the top ? Extraordinary, is it not?

You ask me what is the reason for this curious formation: I am afraid I cannot tell you. It has been sugg ested that its object is to increase the creature's 


\section{THE MAKERS OF GOSSAMER}

range of vision, but this is hardly likely to be the true explanation because, in the first place, the eminences often exist quite apart from the eyes, and, even when any of the eyes are actually placed upon the raised portion, those which are thus elevated are, as a rule, of imperfect structure. The variety in the form of these prominences is remarkable, and the appearance presented by the spiders is often really ludicrous. They are, indeed, the gnomes of spiderland, and the designer of goblin masks for the Christmas pantomimes might well obtain original ideas from the quaint forms of these little creatures. Curiously enough, the strangely formed heads are almost peculiar to the males. Nearly a thousand species have been described, and we have considerably more than a hundred in this country: but practically nothing is known of them except by a few experts. Let us tear up a few tufts of grass by the roots from the bottom of these railings and beat them upon this sheet of newspaper. Do you see those small brown objects scampering towards the edge of the paper? They, also, are Erigones, as the "big-heads" are scientifically termed. The grass in this place absolutely swarms with them, and yet in a similar situation a few yards away you might have difficulty in finding more than a few stray specimens. They seem to be quite fastidious in their selection of a dwelling-place; and although the expert collector 


\section{BRITISH BUTTERFLIES}

knows from experience exactly where he is likely to find any species which he may require, he is, in the majority of cases, quite unable to account for the creature's predilection for that particular locality.

What is that you say? You understand now why these creatures indulge in aeronautical excursions. You think that they leave because the district is not in accordance with their tastes. Without being in any way pedantic, and without forgetting the caution which a long acquaintance with Nature's curious methods has engendered, I am afraid I must again disagree with you. You must remember that the mother spider makes strenuous efforts to place her eggs in such a position that the young spiders, when born, shall be under those conditions most conducive to their well-being. Why, then, should her offspring reject her choice of a home for them and wander far and wide in search of something better? Let me hazard an explanation. The patch of herbage at our feet, as you can see for yourself, seems in every way to fulfil the Erigone's idea of a suitable abode, judging from the fact that in practically every tuft of grass there is to be found one of these small beings resting beneath its frail horizontal saucer-like snare. Think, now, what will be the history of this small patch during the coming season. Within a couple of months the female spiders will have deposited their eggs, and leaving them to the mercy of the world 


\section{THE MAKERS OF GOSSAMER}

will have shrivelled up to unrecognizable specks. The eggs will hatch, even though the weather be still inclement, and several dozen tiny spiderlings will be ushered into the world to take their part in the struggle for existence.

The first problem, naturally, is that of food. Now in this respect spiders are fastidious. True, most creatures are somewhat particular in their selection of viands, and a caterpillar, for example, will often starve rather than partake of green-meat not exactly in accordance with its taste. But the eggs from which caterpillars are produced are usually laid near to an ample supply of the particular kind of food which the moth-mother instinctively knows her offspring will relish, and the difficulty vanishes. With spiders, however, the case is altogether different. Living creatures form their sole nourishment, and, failing this, they must inevitably perish. Now, if you will bring a lens to bear upon the surface of the ground at the roots of our grass-tuft, you will probably be surprised at the hordes of creatures of one sort and another which people the spot, and you may be tempted to suggest that the supply must be amply sufficient for the needs of a dozen or so of tiny spiders. But, without experience in the matter, you can form little idea of the two most potent factors in this little drama-a spider's appetite and a spider's prodigality. As long as suitable 


\section{BRITISH BUTTERFLIES}

food presents itself, or is within a reasonable distance, a spider will kill with the utmost ferocity and eat with as much gusto as if it had not seen food for days.

As long as mites and springtails are to be procured with ease the spider's existence is one of killing and eating. There comes a time, however, when these minute comestibles become so scarce that he finds difficulties even in obtaining the bare necessities of life. He cannot borrow from his brother, for the whole family are probably in the same straits. So he makes the best of a bad business, and, borrowing his brother in person, transfers the liquid portions of his anatomy to his own little maw. The bad habit, once cultivated, soon grows stronger, and the spider, also growing stronger, becomes more and more capable of indulging in his unholy practices. As a consequence, before many weeks have passed, the original family of several dozen has dwindled to three or four well-favoured, robust spiders. Surely, it is not a matter for surprise that one or more of them should wander up a railing and sail quietly away.

And so, in the autumn mornings, when the grass is alive with tiny spiders, young and old, all attempting, with more or less success to change their quarters, the air becomes charged with quantities of their silken emanations; and these threads, wafted hither and 


\section{THE MAKERS OF GOSSAMER}

thither by fickle breezes, gradually become entangled, form visible flocculent masses, and descend to earth. And the rustic calls it gossamer, and blames the fairies for its appearance. 



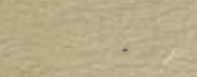

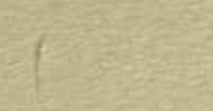

Ex $3 x=$

i 

w'

148 


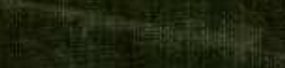

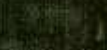

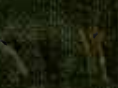

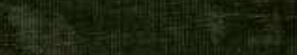

2.

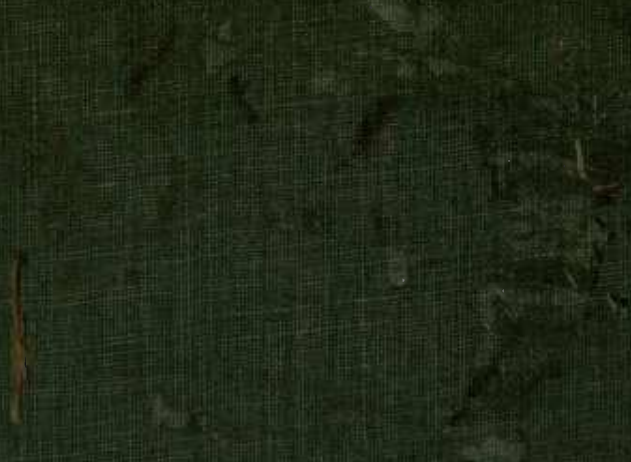

폼 